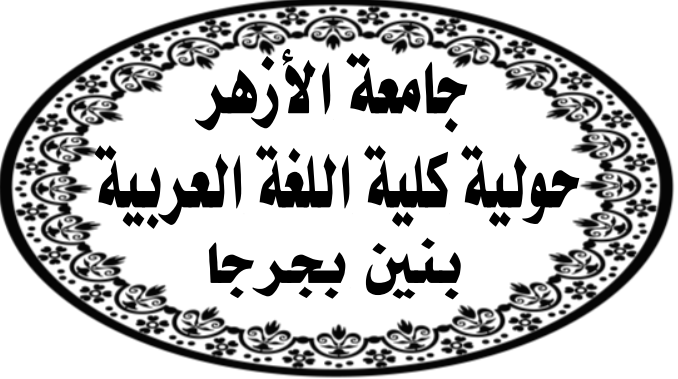

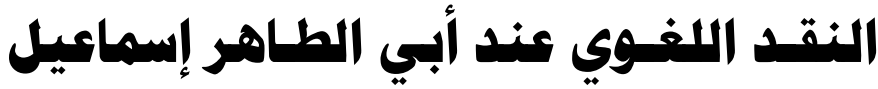

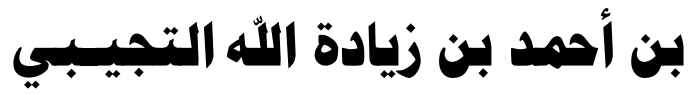

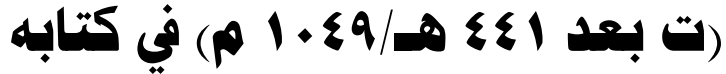

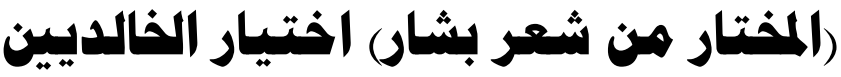
(j)

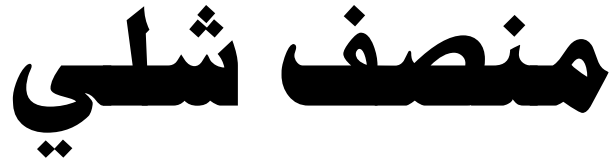

قسم الآداب واللغة العربية، كلية الآداب واللاغات جاهمة الإخهة منتشوري قسنطينة - الجزائر العداد الرابع والمشيدوز Pr.r./.DE\&l.ph

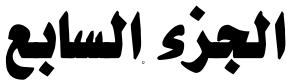

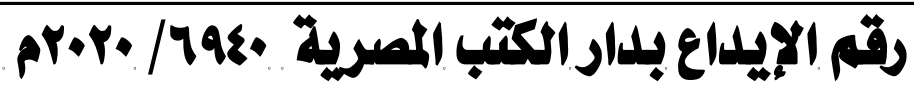

الترقير الدولاد

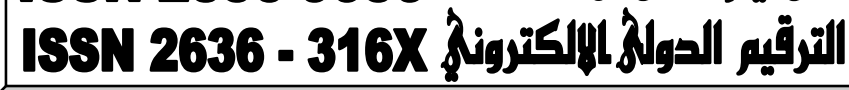




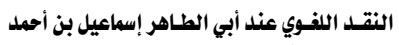

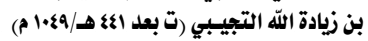
في كتابه (المختار من شعر بشار) اختيار الخاللديين

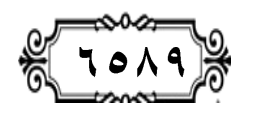

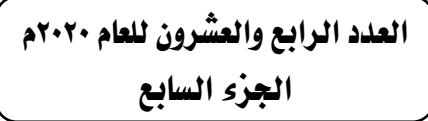

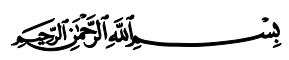

النقـد اللغـوي عند أبي الطـاهر إسماعيل بن أحمد بن زيادة الاله التجيـبي (ت بعد

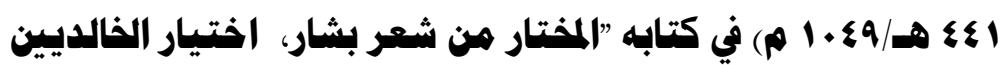

هنصف شالمابي

قسم الآداب واللغة العربية، كلية الآداب واللغات ـ جاهعة الإخوة هنتوري قسنطينة ـ الجزائر

يهدف هذا البحث إلى إبراز الجاتب النقدي في كتاب أبي الطاهر

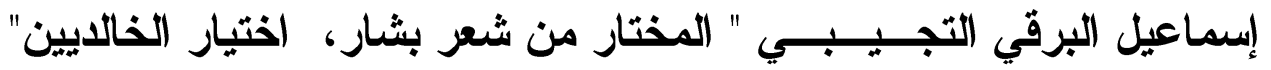

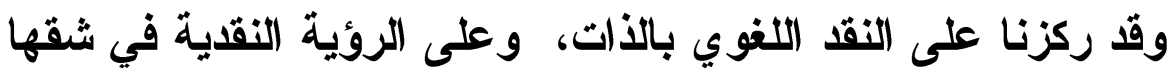

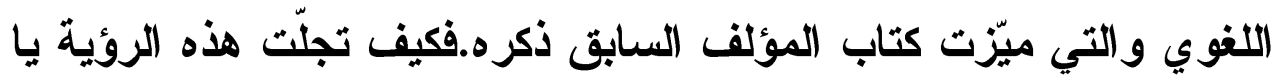
تزى؟ وما هي أهم خصائص النقا اللغوي عند المؤلف؟ الكلمات المتتاحية : النقل اللغوي ، التجيبي ، المختار من شعر بشار ، أبي

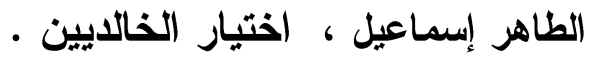


الترقير الدولخ 2356-9050

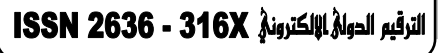
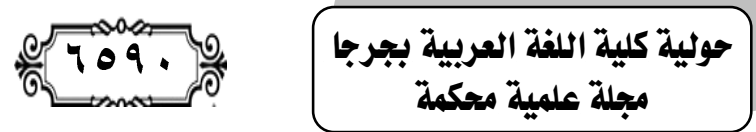

Linguistic Criticism of Abu al-Tahir Ismail bin Ahmad bin Ziyadallah al-Tajibi (d. $441 \mathrm{AH} / 1049 \mathrm{CE}$ ) in his book "The Chosen One of Bashar's Poetry, The Choice of the Khaldis"

\section{Moncef Chelly}

Department of Arts and the Arabic Language, Faculty of Arts and Languages -

University of Brothers Montouri Constantine - Algeria

Email: Chelli.moncef@gmail.com

Abstract

This research paper aims at highlighting the critical aspect of the AbiIsmaeel Al barky Al Tajeeby's book" A selection of Bashar's poetry."

And wefocused on linguisticcriticismitself and the criticial vision in itslinguistic aspect whichcharacterised the author's book previouslyquoted.How did the vision emerge and what are the key linguisticfeatures of the author?.

Keywords: Linguistic criticism, the respondent, chosen from the poetry of Bashar, Abi al-Tahir Ismail, the choice of the Khalidi.

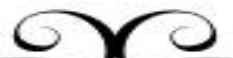




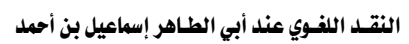

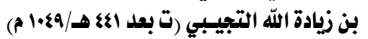

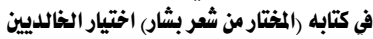

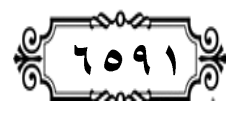

العدد الرابع والعشروز للعام •r.r.

الجزء السابع البعان

حِ

التتمريف بالإؤلف:

هو إسماعيل بن أحمد بن زيادة الله التجيبي من أهل القيروان وسكن المهدية، يعرف بالبرقي و يكنى أبا الطاهر، من أهل اللغة والفضل الوافر، أخذ عن أبي إسحاق الحصري تواليفه ، وسمع من أبي القاسم سعيد بن أبي مخلا الأزدي العُماني، و أبي القاسم عمار محمد الإسكندراني وأبي الحسن علي بن حبيش الثيباني الأديب، كما قرأ على يعقوب بن خرّاز اد النجيرمي ونظرائه من شيوخ مصر، يث روى عنه أدب الكتاب لابن قتيبة، كمــا روى ديوان المتببي عن الحسين بن حاتم الأزدي الذي أخذه عن ابن جنّي

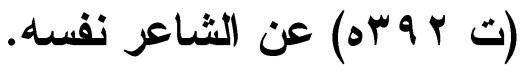

كان أبو الطاهر إسماعيل عالما بالآداب مستبحرا، شاعرا مجوّدا من .

أهل التأليف والتصنيف، مع جودة الضبط وبر اعة الخط، وكان رجلا طوّافا

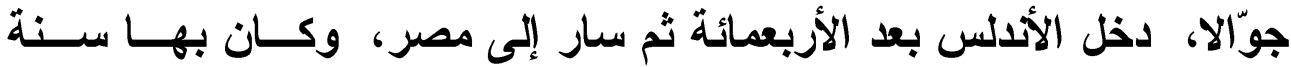
خمس عشرة و أربعمائة، كما أقام زمنا بصقلية حيث ربطته علاقّـات ودّ و صداقة بشاعر تلك الجزيرة الذائع الصيث علي بن محمد الخيـاط الربّعـي، وكان قبلا تلميذا لعبد الكريم النهشلي (ه م عه).

حدّث عنه خلق كثير في مشرق العالم الإســلامي ومغربـــه، لعـلـ أبرزهم علامّة الألدلس أبو مروان الطبني الذي لقيه بالإسكندرية في رحلـة لأداء الفريضة، وكان وقوفه فــي موسم ثمان وثنلاثين وأربعمائةة. (1)

(1) حول ترجمته ينظر المصادر الآتية: ابن الآبار القضاعي: التكملة لكتاب الصــلة، تحقيـق:

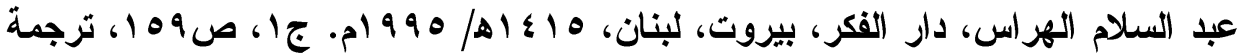
رقم(1 +0)،/السيوطي: بغية الوعاقفي طبقات اللغويين و النحاة، تحقيق: محمد عبدالرحيم =

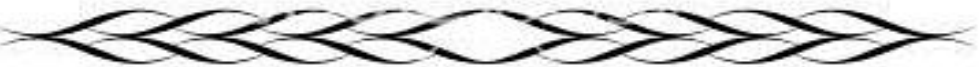




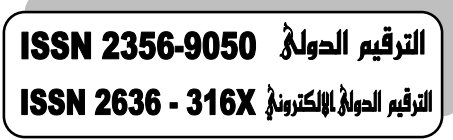

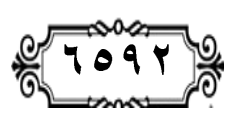

حولية كلية اللفة العربية بجرجا مجلة علمية محكمة

وكــان أبو الطاهر إسماعيل بن زيــادة الله التجيبي لا يـز ال عــلى قيد

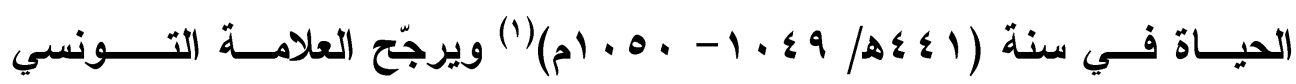

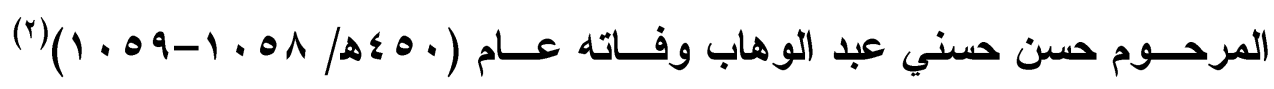
آثاروها

يفول الاكتور الثاذلي بويحيى: "ونحن لا نعرف من آثــاره ســوى شرحه لأثُعار بشار بن برد المقتطفة من كتاب الاختيار من شــر بشـــار،

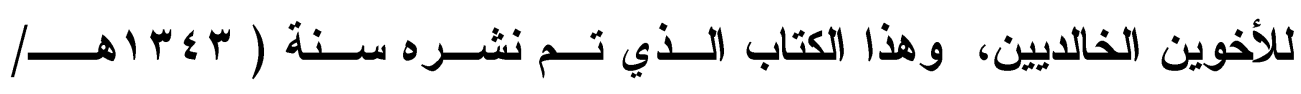

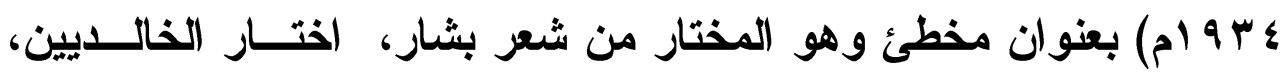

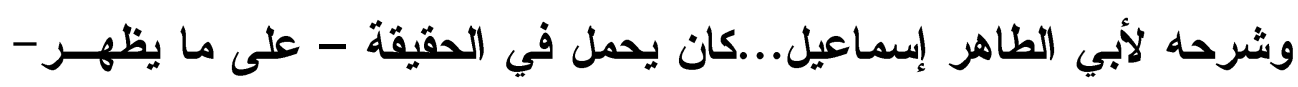

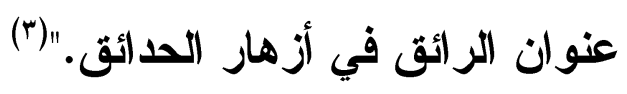

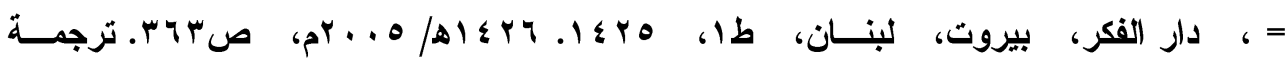

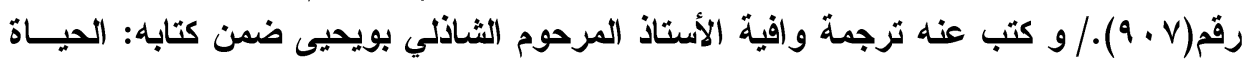

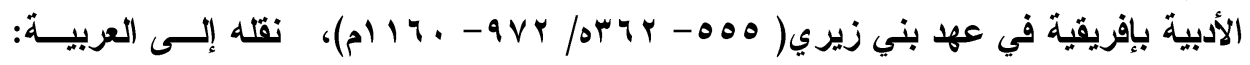

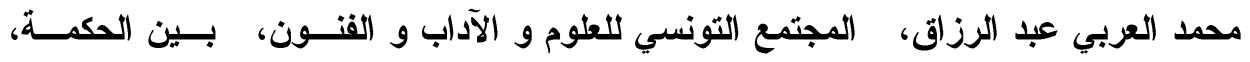

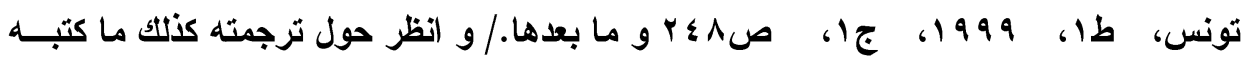

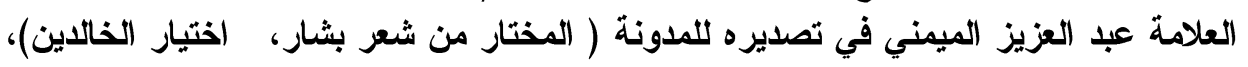

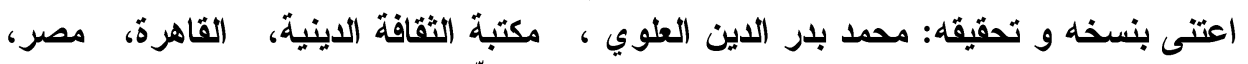

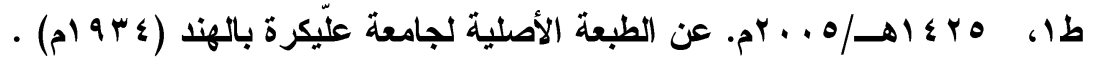

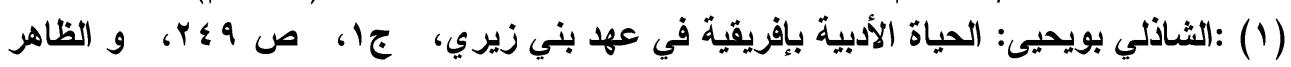

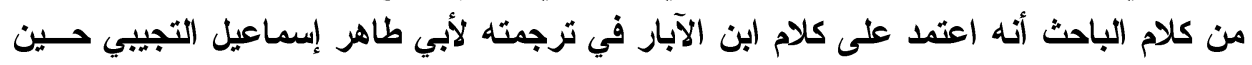

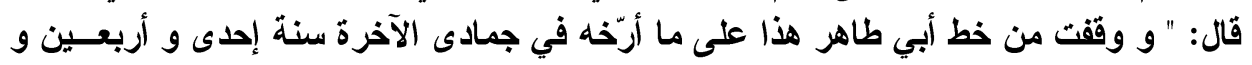

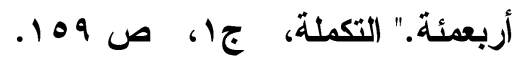

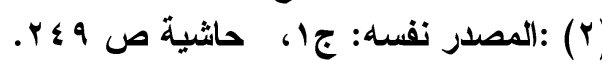

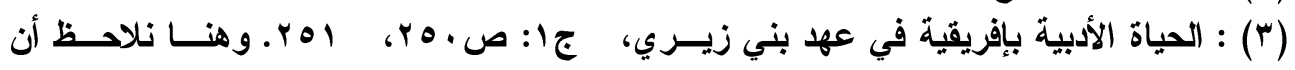

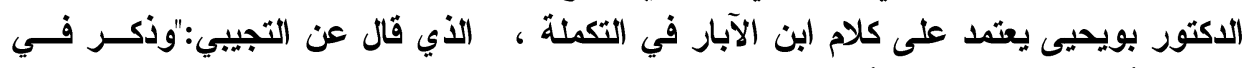

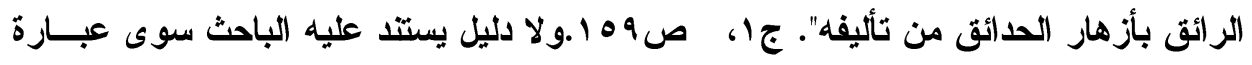

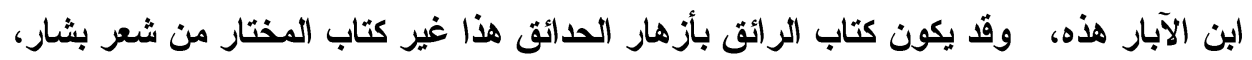
وقا يكونان كتابا واحدا. 


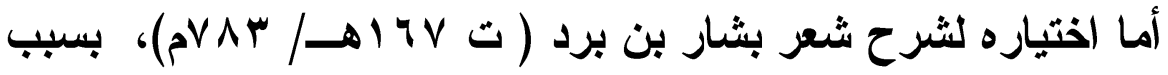
ما لقاه شعر هذا الثاعر من قبول في البيئة الأدبية العربية من شرقها إلـى لـى لـ

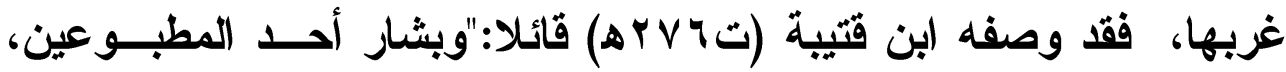

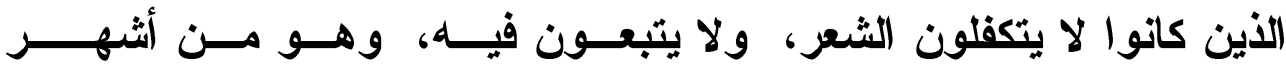

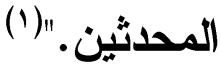

وبلغت غزارة شعر بثار بن برد و كثرته، بحيث لم يجتمع شــره

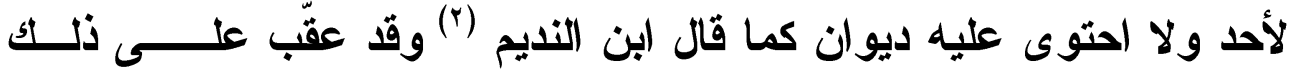

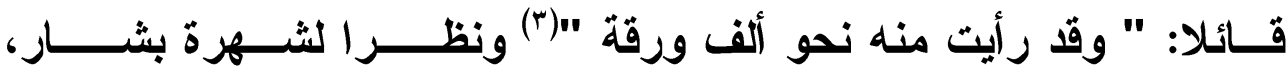

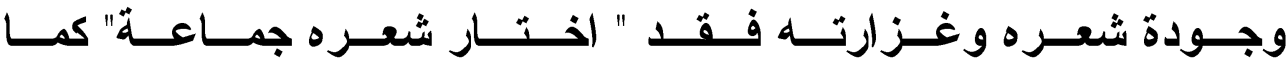

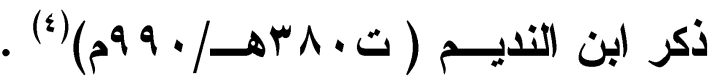

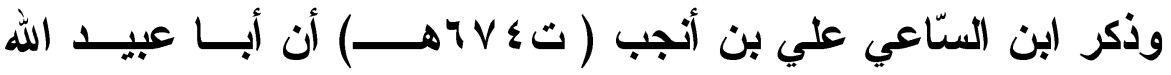

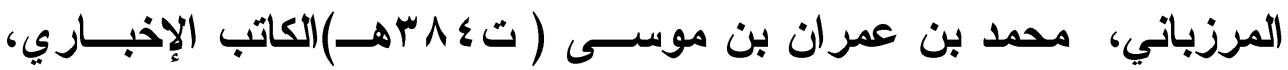
قد صنف كتابا في سير أخبار الثُعراء المشهورين والمكثرين من المُحثين،

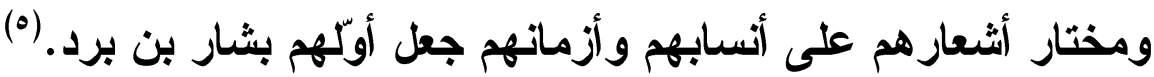

(1) : الشعر والثعراء، تحقيق وشرح:أحمد محد شاكر، دار الحديث، القاهرة، مصـر،

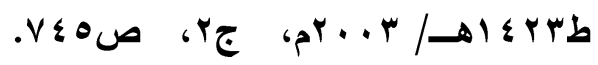

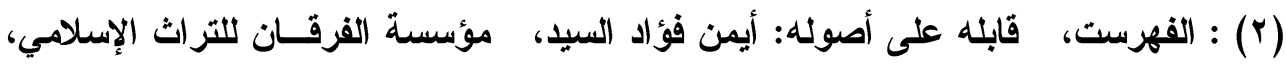

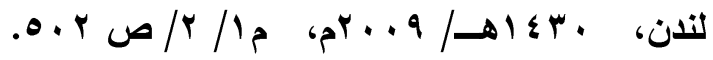

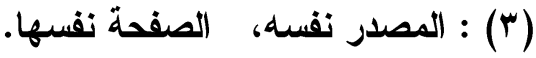
( ) ( ) : المصدر نفسه، الصفحة نفسها. (0) :الدر الثمين في أسماء المصنفين، حققه وعلق عليه: أحمد شوقي بنبين ومحمد ســيد

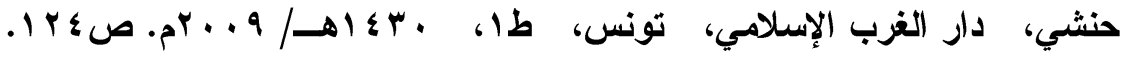




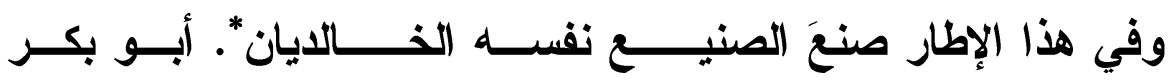

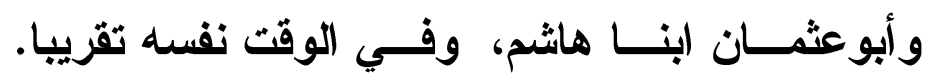

وياخل اختيار الخالايين لشعر بشار بن برد، في سياق اختياراتهـــا

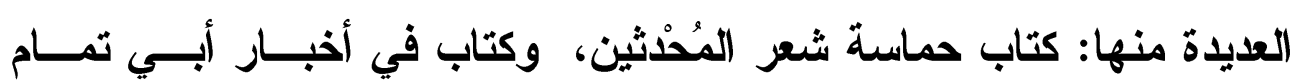
ومحاسن شعره، وكتاب في اختيار شعر (بن الرومي، وكتاب فئسي اختيــار

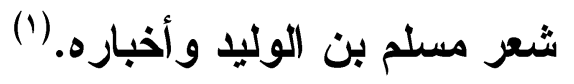
هنهج الموألف في الكتاب: الظاهر من الــمُصنَّف أنه شرح لاختيارات الخالايين من شعر بشار

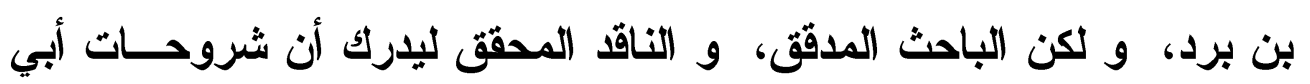

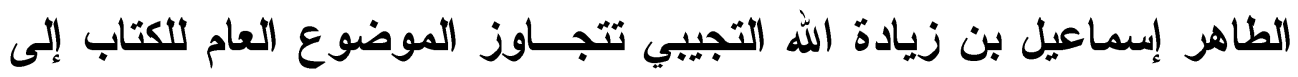

محمد وسعيد إبنا هاشم وهما من قرية من قرى الوصل تعرف بالخالدية، و كنا شـاعرين

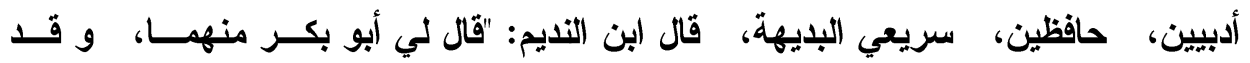

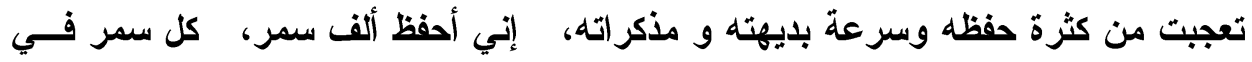
نحو مائة ورقة". وكان الخالديان قد مدحا سيف الدولة ابن حمدان. وقات عمل أبــو عثــــان

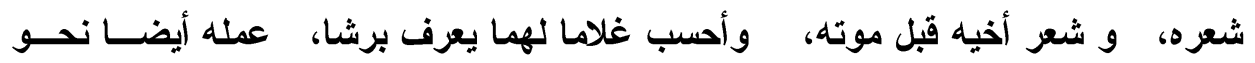
ألف ورقة، كما يقول ابن النديم.

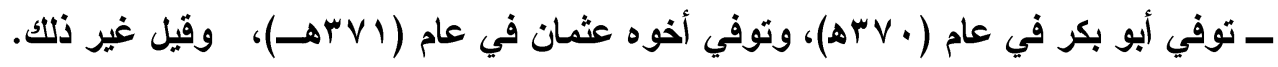

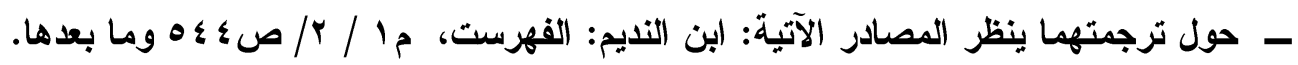

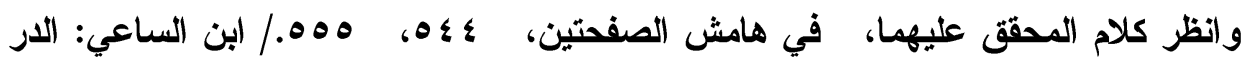

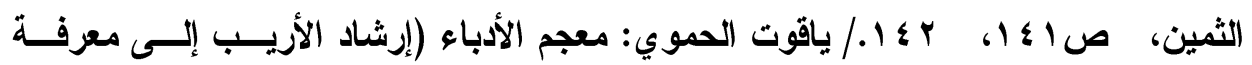

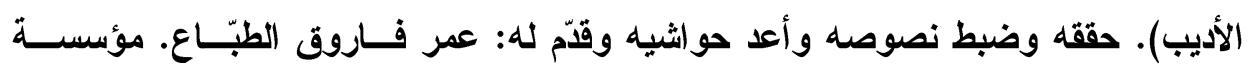

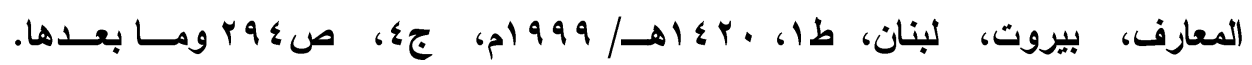

$$
\text { وفي غيرها من المصادر. }
$$

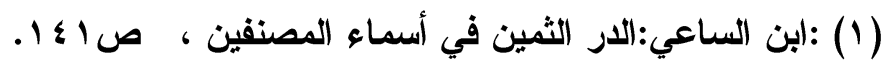




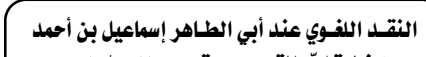

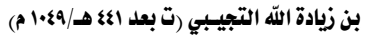
في كتابه (المختار من شعر بشار) اختيار الخالديين

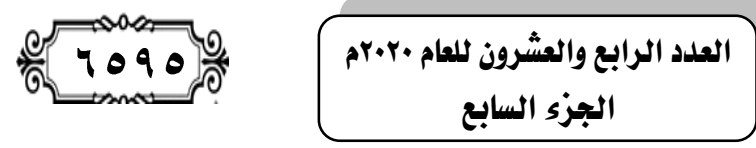

تفاصيل أخرى أوسـع وأدق، إنه كتــاب أدب عــام يتمثـــل موضوعــــهـ ويتجاوزه إلى مواضيع أخرى.

وكاتت الاستطر ادات هي السمة الغالبة للكتاب، هتى ليتساءل الباحث أحيانا حول الموضوع الرئيس للمدونة، أهو شرح لشعر بشار؟ أم هو كتاب أدب عام على غرار كتاب البيان والتبيين للجاحظ(ه به ه)، أو عيون الأخبار

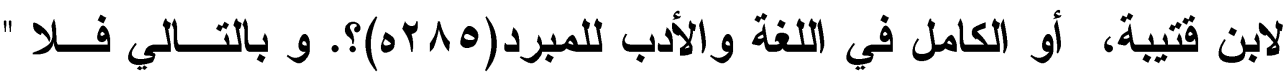
يظهر أن الكاتب يحتذي خطّا معلوما يسير عليه في اختيار الأبيات، ولا أنه يتبع منهجا معينا في التأليف، وكأنه يميز بين جزء أول من الكتاب وجـزء

(1)" ثنان يليه

وربما قصد إلى ذلك قصدا، جريا على سنن من قبله من المــؤلفين العرب، يث يقول: " وإذا أفضنا في هذا الحديث ، وأفضينا إلى هذا الباب، فسنذكر منه أوصافا تفرّد بها هذا الجزء من هذا الكتاب؛ ليكون معنى علـى

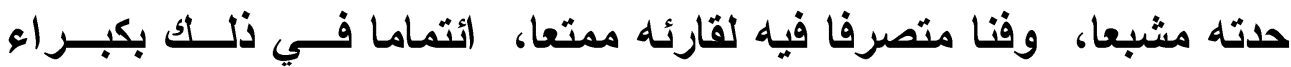
المؤلفين، وجريا على مناهج فضلاء المصنفين، واختلاطا بملكهم وانخر (ط)

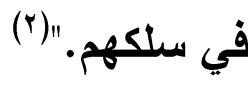

وقد يأتي بأمثئة لا تتـاسب الباب الذي هو فيه ولا ضير، إذ كــان قصده الإمتاع، ها هو يقول معقبا على أبيات شعرية للشاعر كثير عزّة " وها

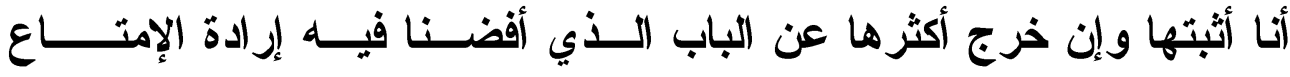

وإتـــــاف الأسماع" (َ)

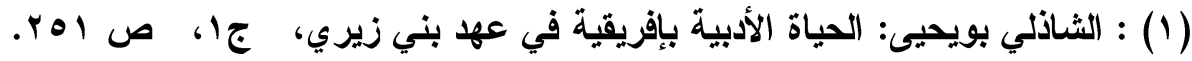

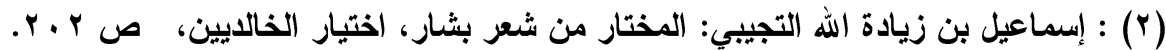

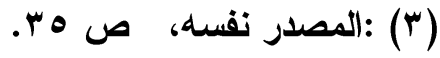


وعادة ما ينتقل من باب إلى باب ويستخلم لذلك صيغا صريحة مثـلـل

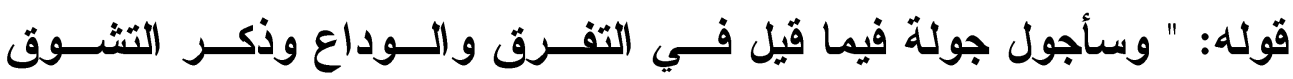
والاكتياع." (') وله: (1)

وقد يختصر شعر أو مقطعة، و ويصرّح بذلك قائلا:" وقــال الأغلـبـ

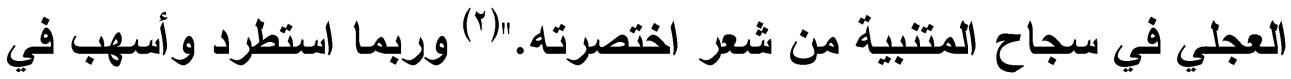

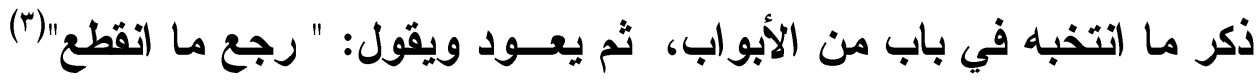
وقد يحصل التردد في انتخاب أبيات شعرية، و والدافع هــو الــوازع

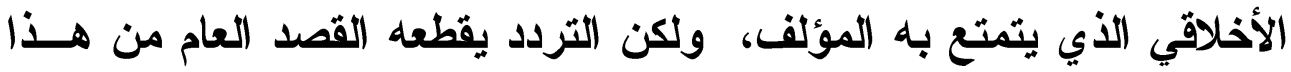

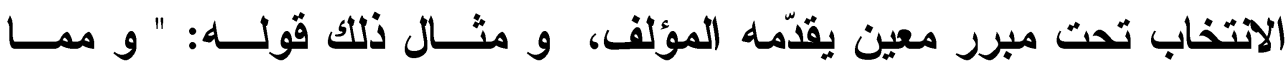

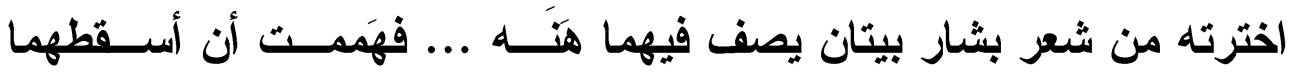

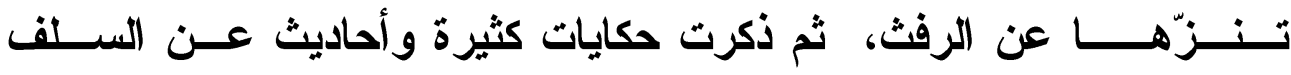

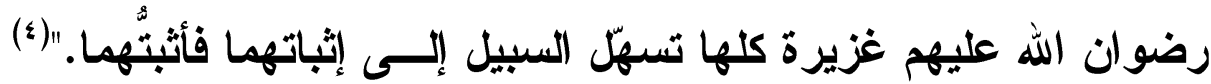
و هكذا يمضي في منتخباته الثعرية وشروحاته و استطر اداته الأدبيـــة إلى آخر الكتاب، هيث يختمه قائلا: " إلى ههنا انتهى اختيارنا فيما وجدناه

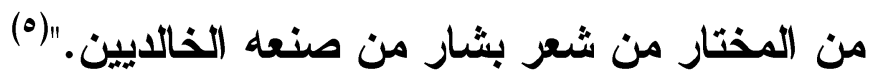

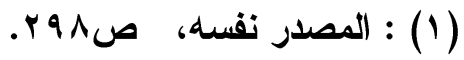

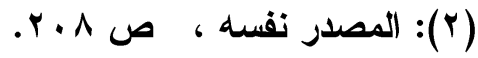

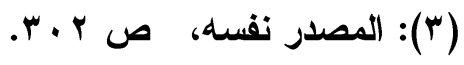

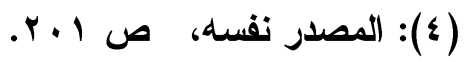
(0): المصدر نقسد، ص اء 
النقد اللغوي في كتاب أبي الطاهر إسهاعيل التجيبي:

إذا كاتت الاختيارات الثعرية تعبر عـن الحس النقدي الأي يحــوزه

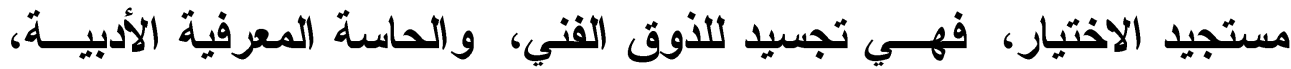
إذ الأوق هو أســاس الحكم القنــي، والحكم الفني هو النقا عينه. وبالتالي فإن الثروحات الواقعة على هذه الاختيارات هي نقد كذلك،

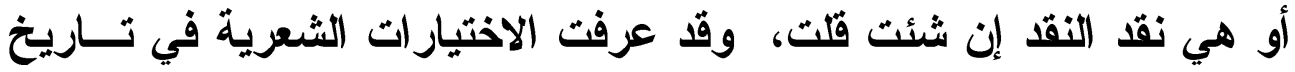

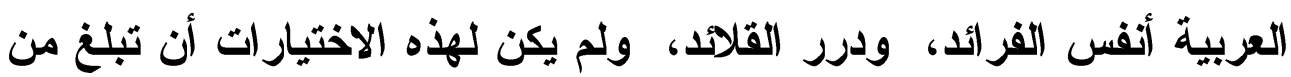

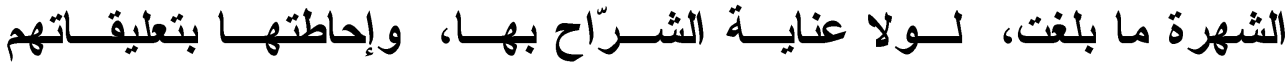
وتصويباتهم، وآرائهم القيّمة ورؤاهم السديدة. ويأتي شرح العلامّة أبي الطاهر إسماعيل بــن زيــادة الله التجيبـي

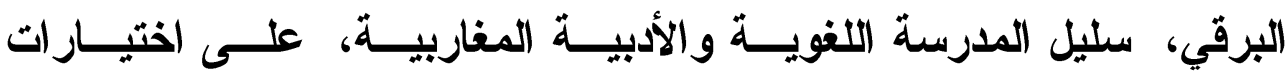
الخالديين من شعر بشار في هذا العياق.

"إن الناظر في التراث الثعري يجد أن الاراسات التي قامــت حولــهـ

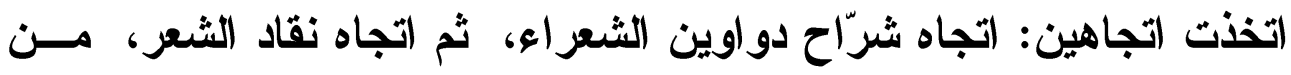
خلال ما يسوقون من آراء في النقد والأدب. أما شراح دواوين الثعــراء فكانـــــوا أقــرب إلـــى أن يكونـــــوا أصحسـاب لغة أو أهل نحو، أو علماء في الأدب."((') إن الباحث الحصيف ذو العين الناقدة و البصيرة الناقذة ليــرك مسن خلال قزاعته لهذا الثرح، الروية النقاية المتكاملة التي يحوزهـــــــارح (1): طه مصطفى أبو كريشة: النقا العربي التطبيقي بين القـديم والحسـيث، مكتبـة لبنــان

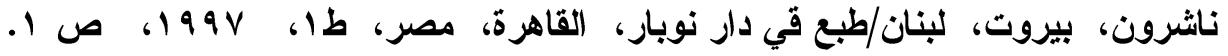

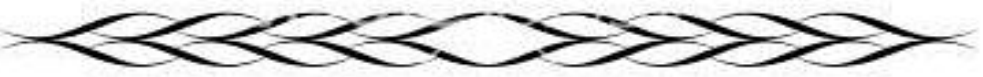


الاختيار، فقد أنبأت هذه الروية عن وجود ناقد متكامل في منهجه، و واسـع في رؤيته، يحتكم في شرحه للمثل والثـاهد والمقطعة والقصيدة، والأبيـات المفردة وغيرها.

وإذا كان النقد اللغوي في أبسط مفهوماته "يسعى إلى صون اللغة مسن

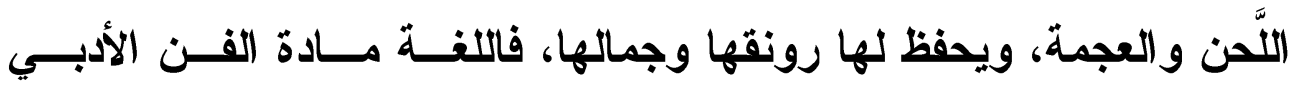
وأساس نبوغ الأديب وتفوقه المتمثل في طريقـــة تناولـــه اللغـــة و التعامـلـل

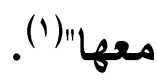

فاللغة هي لباس النص والحاملة لجوهره ومضمونه وبالتالي"فالنص لا ينفصل عن المادة التي تحمله"(؟)و إذا اعتبرنا النص أحد الأعمــدة التــي ترتكز عليها الثقافة العربية القديمة، تبينت لنا أهمية المادة الحاملــة لهـــه النصوص، فعلى الناقد إذن أن يولـيَ هذه المادة أو"هذه الأداة أو الوســيلة عنايته واهتمامه، ويصرف إليها جهده، لأنها الموضوع الأول للنقد، ولأتهـــا الحقيقة الأولى في الفن الأدبي، والأساس الأي ينطلق منه الناقد في معالجة

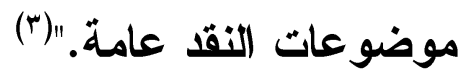

وقد اضطلع نقاد اللغة عامة بمهمة تلمس مواطن الصحة والخطأ، أو الجمال والقبح في النصوص الأدبية وخاصة النصوص الثعرية، سواء على مستوى اللفظة المفردة أم في تركيبها العام وموقعها في الجملة.وخاصة بعد

(1) : ثائر عبد الزهرة لازم البصير : أمسـالي المرتضى، بحث في المنهج والنقــــ والتأويـل،

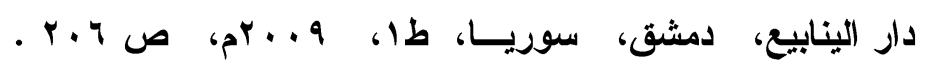

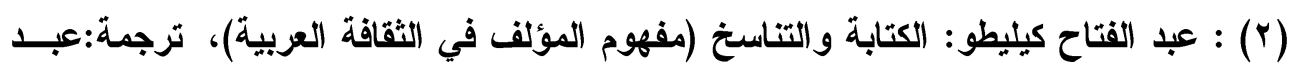

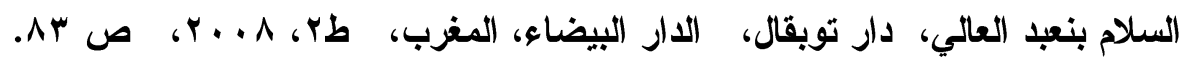

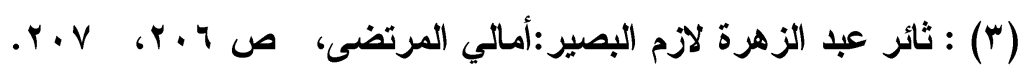




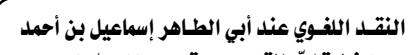

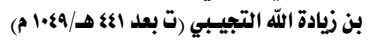
في كتابه (المختار من شعر بشار) اختيار الخالديين

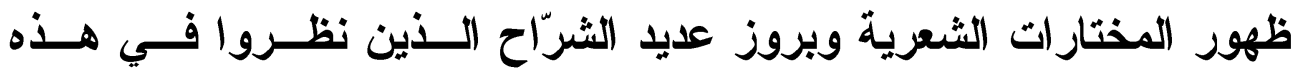
المختار ات، وتعقبوها من حيث بنيتها اللغوية وموافقتها أو مخالفتهــا لمــا تو اضع عليه العرب في لغتهم، ونظامها المتعارف وسنن العرب وهلايها فــي كلامها.

و إذا كان هذا المنهج قد ظهر في القرن الثالث الهجري مـــ ظهـور

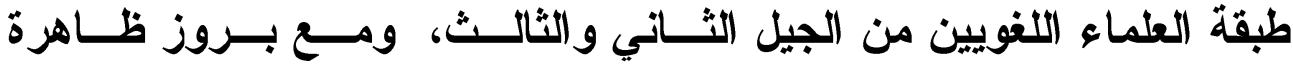
الاختيارات الثعرية، فإنه استمرّ بعد ذلك حتى "عند النقاد التطبيقيـين فئي القرنيين الر ابع والخامس حيث اعتمدوا مقياس نقد الألفـــاظ وطبّةــوه فـــي ممارستهم النقدية، وحكموا من خلاده على الألفاظ بالجودة أو الرداعة، ذلك

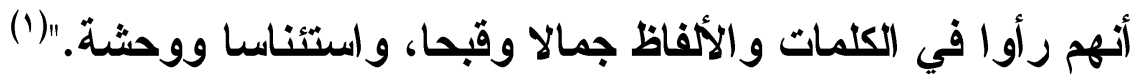
ولا عجب في ذللك، فالثشارح/الناقد، والذي يعتني ببنيــة النصــوص المختارة من حيث الألفاظ ومعانيها، إنما يتذذ على عاتقه مهمة ضبط النص في شقّه اللغوي."وتعل هذه من المظاهر الضرورية لخدمة النص، فإذا كــان

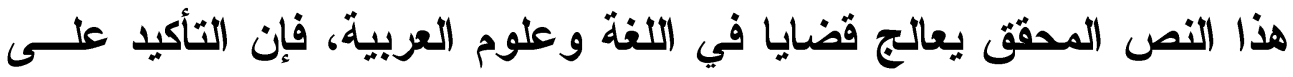

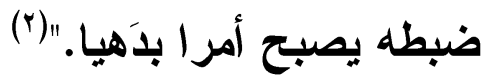
وكان أبو الطاهر إسماعيل يتعامل مع مختــارات الخالــيين لثــر

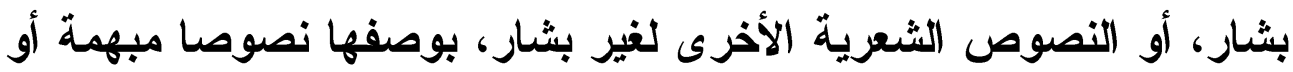

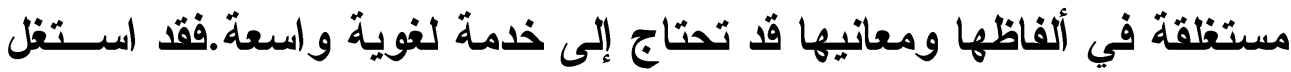

(1) : أحمد محد نتّوف: النقّ التطبيقي عثد العرب في القرنين الرابع والخـامس الهجـريين،

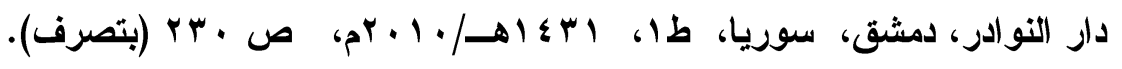

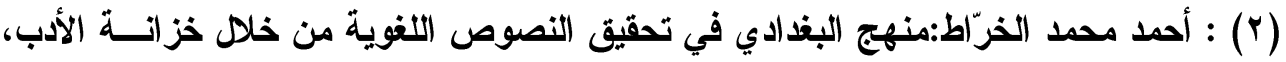

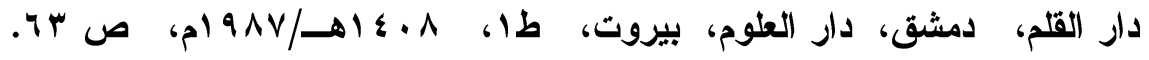




\section{الترقير الدولخ 2356-9050

الشارح/الناقد طاقاته اللغوية ومعرفته الواسعة بها بشكل خاص، فجاء عمله دقيقا، مستوسعا، متفحصا في غاية الاقة والاعتناء.

وهو زيادة على ذلك دقيق في شروحه اللغوية، مصيب في تفسيراته

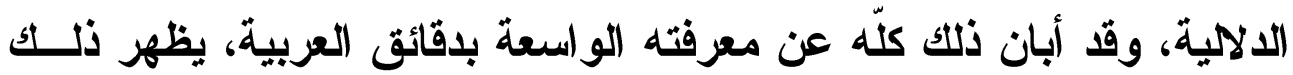
من خلال تعليقاته وتنوع شواهده، فقد كان يعـرف كيـف تتهـق المعـاني

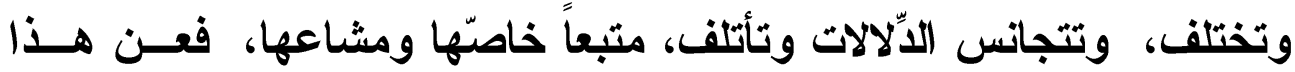
الحس اللغوي، وعن هذه الخلفية المعرفية باللغة بنى الناقد رؤيته النقديــة وتبلورت شروحاته اتجاه هذه المختار ات. وهي قضــية جوهريسـة بالنســبة لرجل مثٔل ابن زيادة الله التجيبي الأي يدرك أن"الكلام هو الأي يعطي العلوم منازلها، ويبيّن مراتبها، ويكشف عن صورها، ويجني صــنوف ثمرهــا، ويدلّ على سر ائرها، ويُبرز مكنون ضمائر ها."(1)

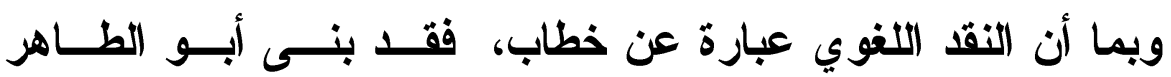
إسماعيل هذا الخطاب ورام إلى تحقيق مقاصده إلى طرق لابدّ منها لتحقيـق هذه المفاصد والمر امي، والبلوغ بالنص وشروحاته إلى مستوى معين من وضوح المعنى وتبيان الدلاكة، بل إلى الصــورة المثالـى مــن استيضــاح مضمون هذا الخطاب، وكان التفسير اللغوي هو الآلية المعتمدة، إضافة إلى كل الآليات التي تصنع المعنى للانصوص الشعرية المختارة.

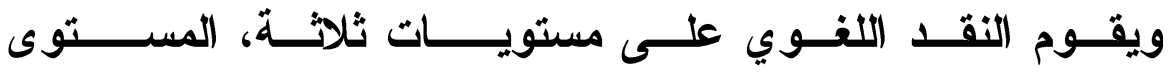
المعجــي، المستوى الصرفي، والمستوى الإعر ابي.

(1) : عبد القاهر الجرجاني: كتاب أسرار البلاغة، قرأه وعلّق عليه :محمود محمد شاكر، دار

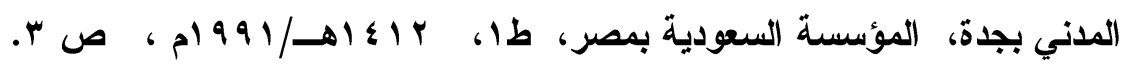


أماً الثروحات الثعرية بشكل عام فإنها تتخذ مسارات ثلاثة حسبـ أحد الباحثين: مسارا باتجاه الألفاظ تحليلا وفكاً، يعقبه مسار باتجاه المعاني كاتي بيانا و اكتثافا و إظهار ا واستنباطا وتوليدا واستصفاء ورفعا وكثفا، ومسارا باتجاه خطة النص وشرحه تركيبا ويناءً. (') وفي خضم كل ذللك استطاع أبو الطــاهر إبــــاعيل بـن زيــادة الله

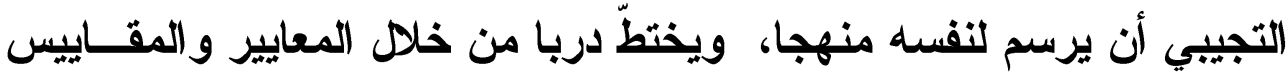
التي استخدمها في شروحاته، والتعاليق التي وظفها على اختيارات الخالايين

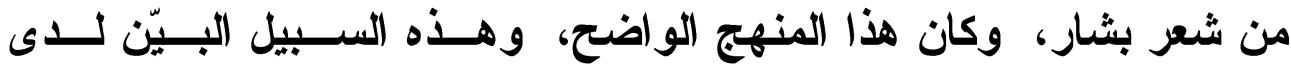

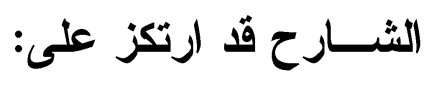
أ-التفسير اللغوي (الثرح):

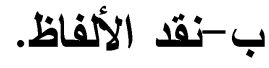
ج-تقد المعاني. وسيجيء لكل هذا زيادة بسط فيما يستقبل.

\section{أ-التفسير اللغوي (الشرح):}

بما أن النص" يكون عادة عسيرا أو غامضا أو غنيا، فإنه لابدّ مـن

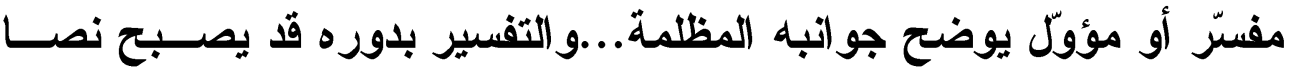

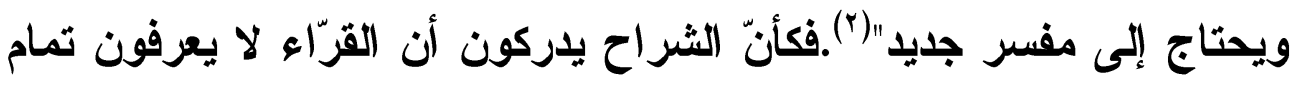
المقصود من الكلام، أو من النص الثعري فيرومون الثرح لتبيان تمامه.

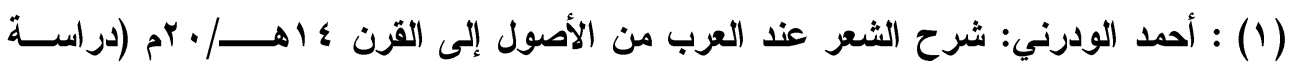

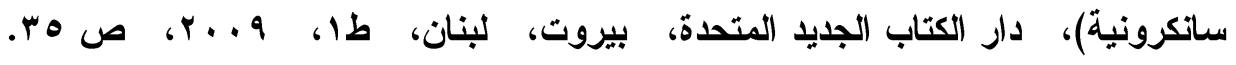

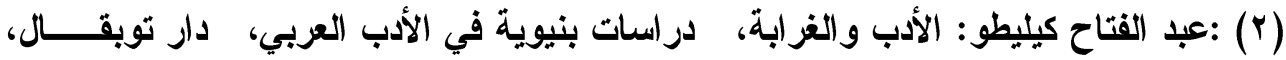

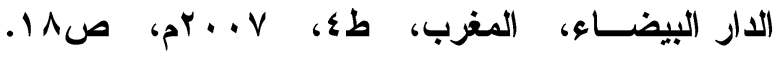


وعلى هذا الأساس فقد غاص التجيبي في شرح ألفاظه وبيان دلالتها،

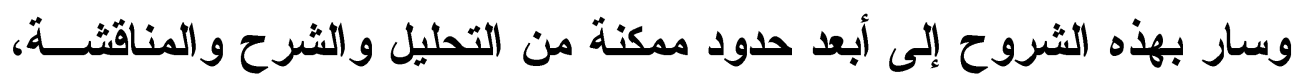

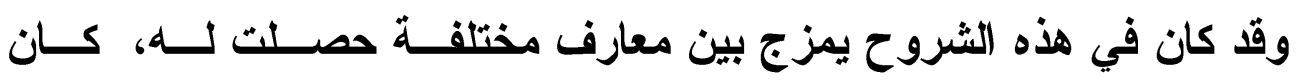
النصيب الأوفر منها لمعارفه اللغوية والنحوية والصرفية، و والثقافة العربية

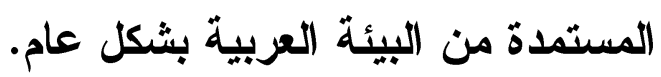

كان منهج أبي الطاهر إسماعيل التجيبي في التفسير اللغوي يحمـل

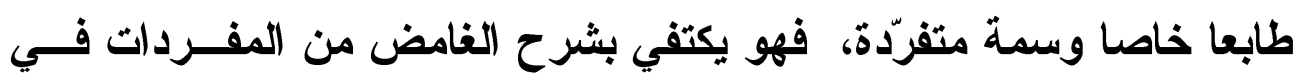

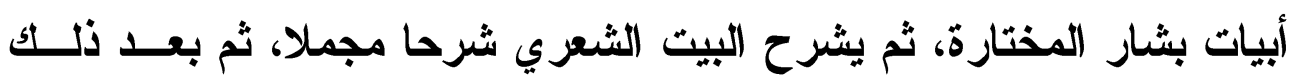

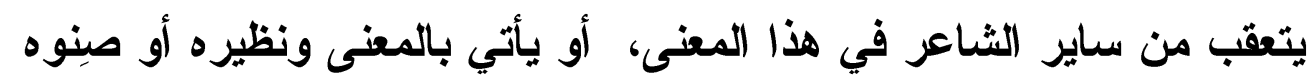

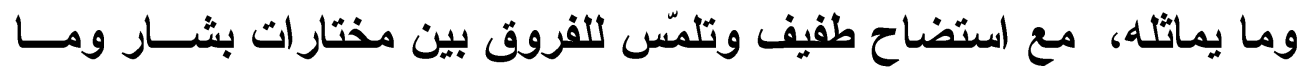

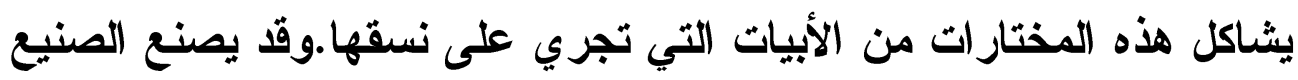
نفسه مع باقي النصوص الثعرية التي يسوقها في شرح هذه الابت المختارات.

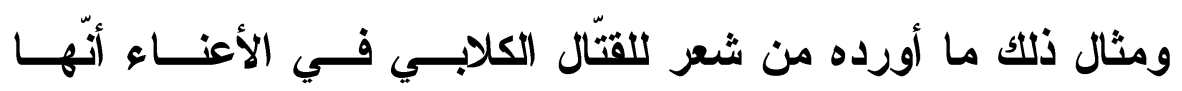
النواحي:

\section{عفت قردة من أهلها فجنابها //// / فحرّة ليلى سهلها وهضابُها}

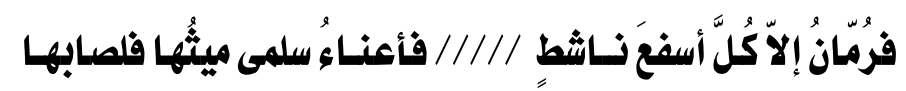

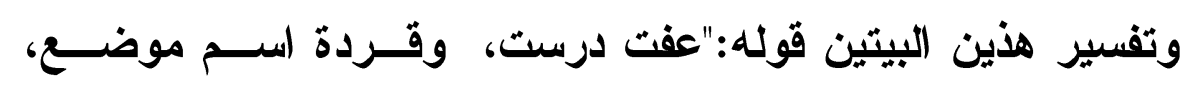

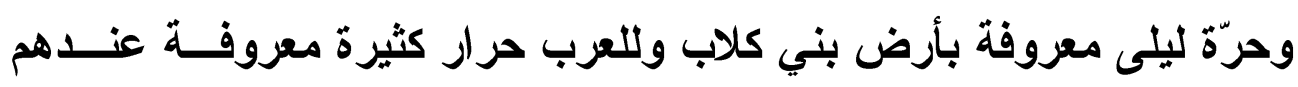

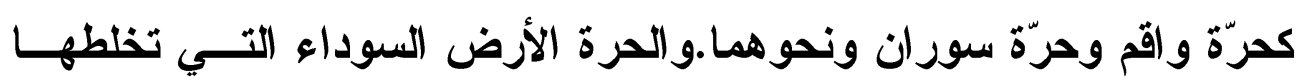

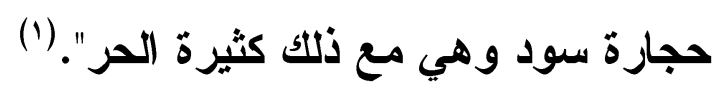




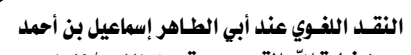

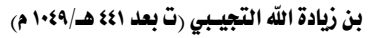
في كتابه (المختار من شعر بشار) اختيار الخالديين بـ الخين

وقد يكون شرحه للغريب شرحا موجزا لا يتجاوز اللفــ الواحسـ أو

السطر الواحد والسطرين، وقد يصل إلى فقرة صغيرة. فقد فسر شطر بيت

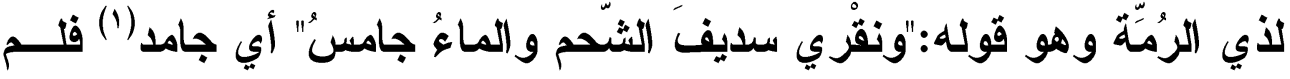

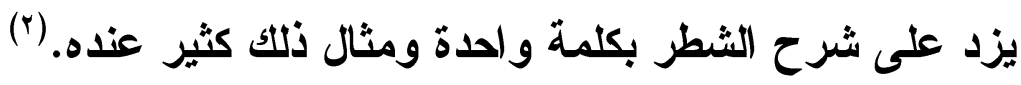
وقد يطول التفسير فيتعدى صفحة وقد يطول جدَّا ويستفيض فيصـل إلى صفحات عديدة حتى ليخيّل للقارئ أنّ هذا الثرح إحدى مواد أو فصول

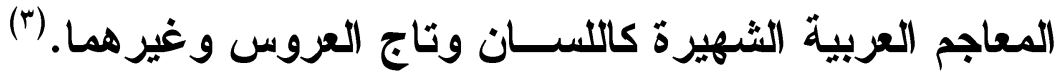
وقد يحيل الثارح في ذكره لبعض الأبيات الثعرية على شرح سابث

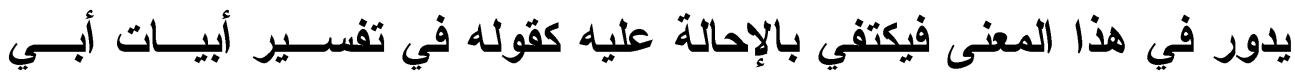

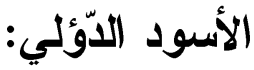

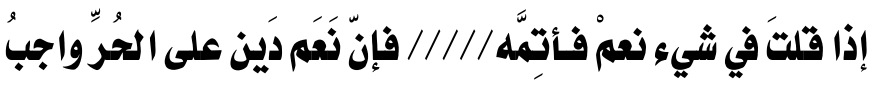

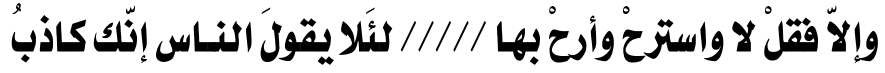

وقد مرّت له نظائر فيما سلف من الكتاب.(؛)

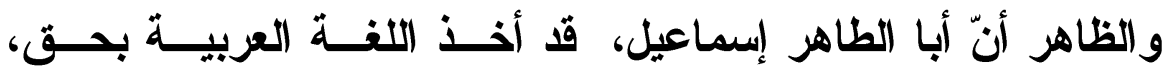
وجرى فيها على عرق، فهو الجواد المُبرِّز في ميدانه مقارنة بجيالــهـ مــن

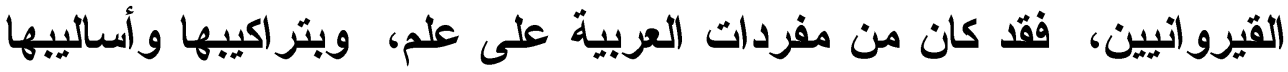
على دراية و فهم، وكاتت طريقته في التفسير اللغوي متميزة مسن حيــ

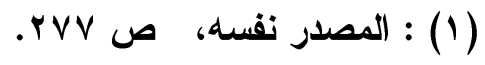

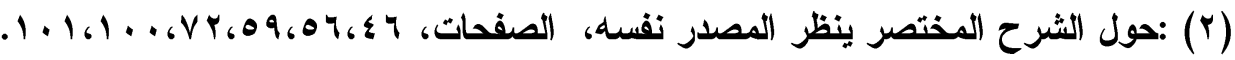

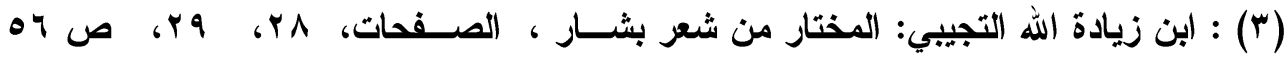

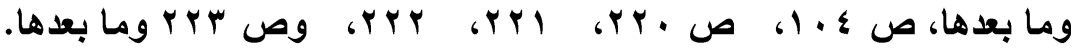

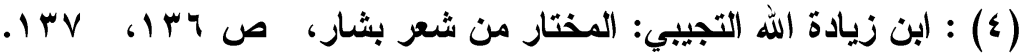


اهتمامه بالألفاظ ودلالاتها المختلفة، و والمعاني وتقليباتها المتعـددة، وكــان دأبه في ذلك وديدنه هو الإكثار من الثواهد المقربة للمسألة من وجوهريـا

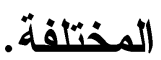

أما النصوص التي سنستشهـ بها في شروحاته المختلفة فقد كاتت كالآتي:

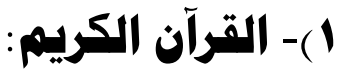

كانت البلاغة القر آنية، هي العجة الأولى لاستشهادات أبي الطَّــاهر

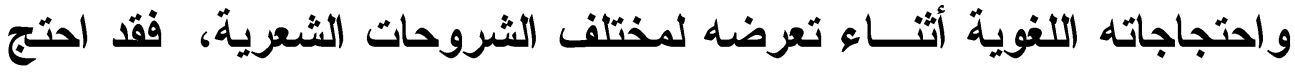

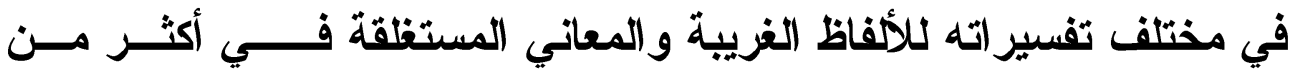
أربعين مرّة. ففي تفسيره لبيت الثاعر :

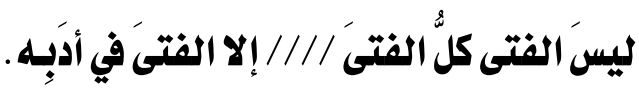

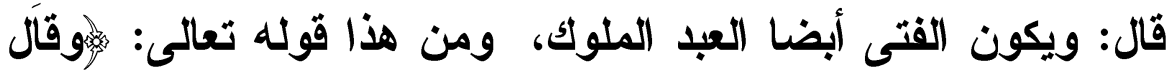

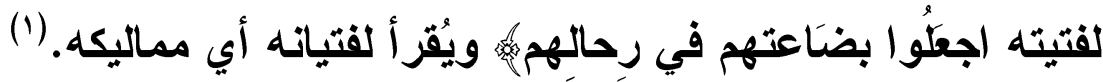

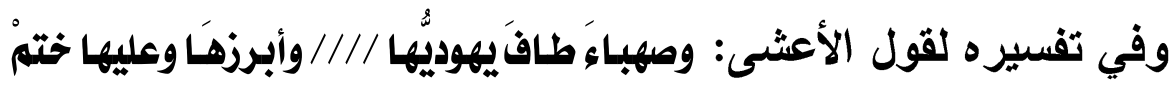

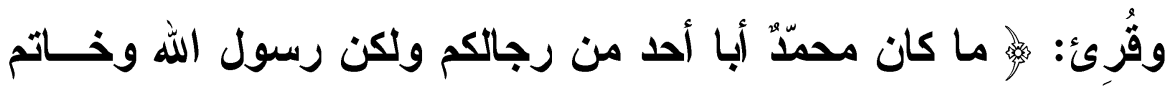

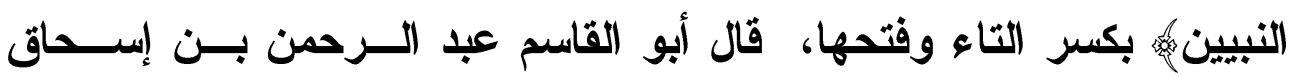
الزجّاجي النحوي: من كسر التاء فمعناه عليه السلام ختم النبيين ومن فتحها

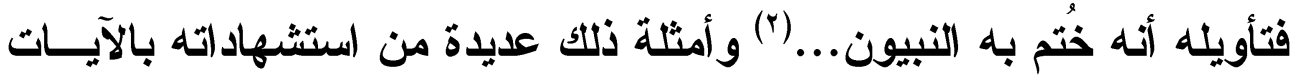

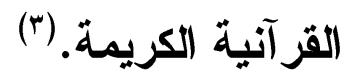

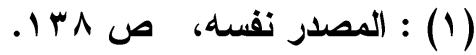

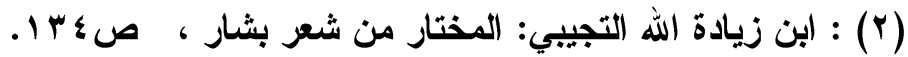

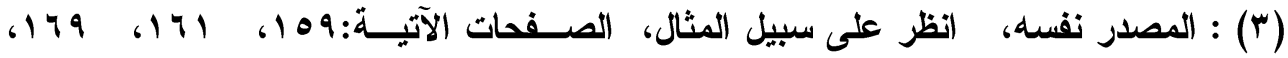




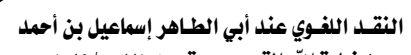

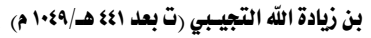
في كتابه (المختار من شعر بشار) اختيار الخالديين الخدين

واستعرض ابن زيادة الله التجيبي مهارته اللغوية ومعارفه في هــا

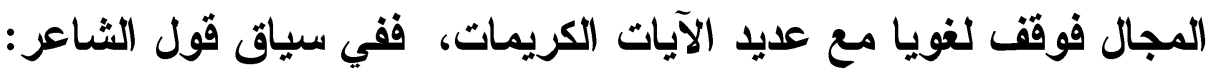

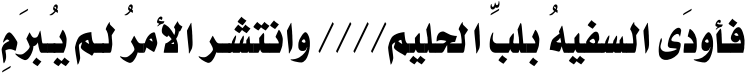

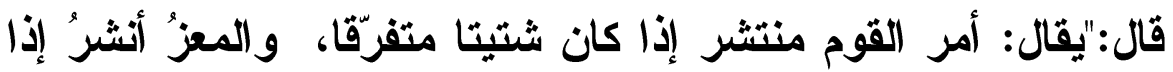

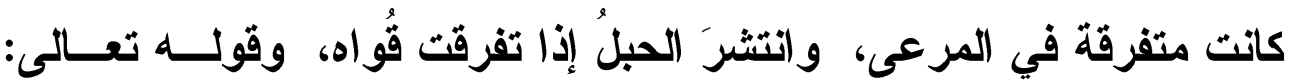

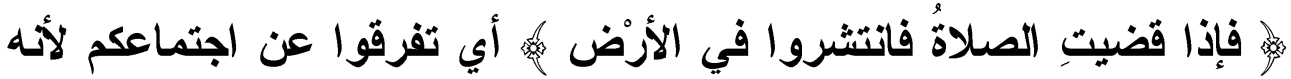

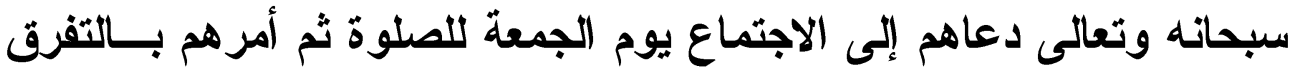

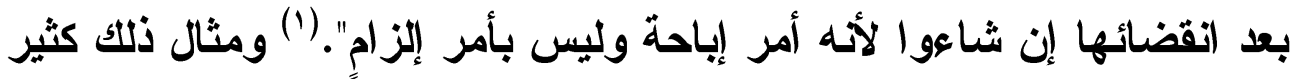

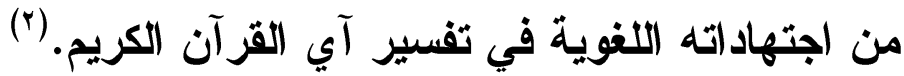

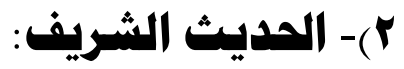

كان حظ الحديث النبوي الثريف من استشهادات التجيبـي عظيــا، حيث إن منزلة الحديث تلي منزلة القرآن الكريم، وكان أبو الطاهر إسماعيل

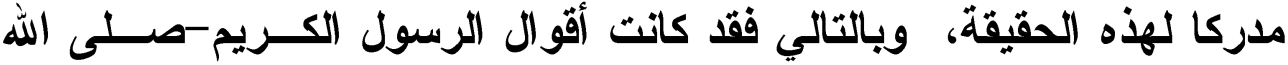
عليه وسلم- حجة لغوية لكل التفسيرات المقدمة من طرف الشارح. ومثال ذلك ما أورده من قول الثاعر:

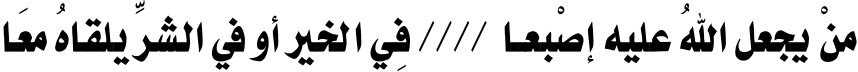

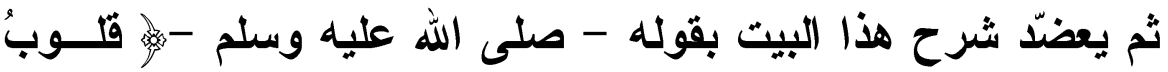

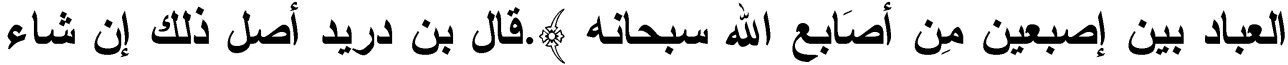

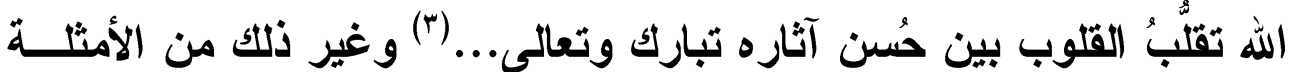

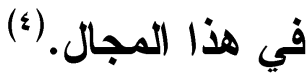

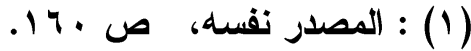

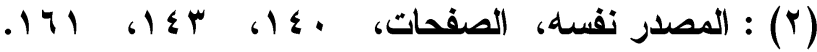

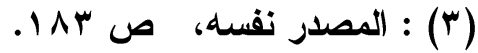

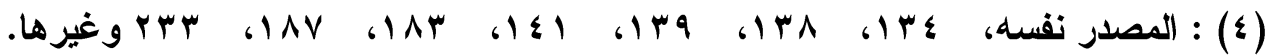


r)- الاحتجاج بأقوال وآراء الصحابة والتابعين وبعض المفسرين: احتجّ الثشارح في تفسيراته اللغويــة، بــأقوال كبــار الصحــــابة و التابعين والمفسرين وأهل العلم ممن كانت أقو الهم وآراؤهم حجة عند أهل

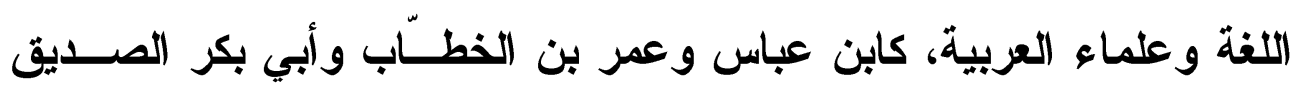

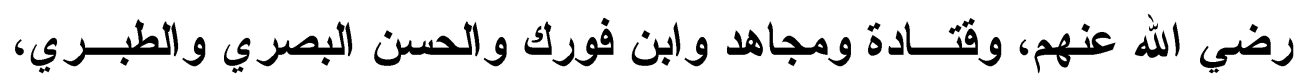

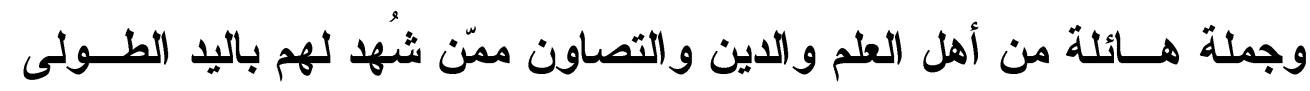
في العلم، وسعة المعسارف اللغوية إلـى جاتب المعارف الدينية و الثرعية. حيث نجده مثنلا يستثه بقول ابن عباس رضي الله عنهما في تفسير

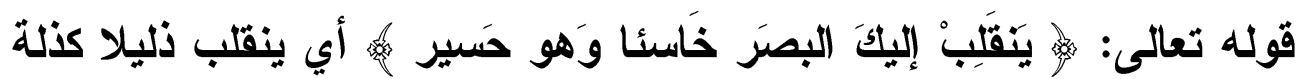

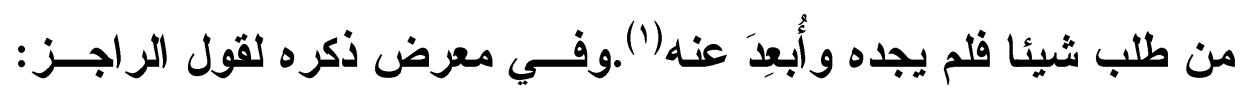
من ذبّ منكم ذبّ عن حريمه /// أو فَّ منكم فرّ عن حريمه

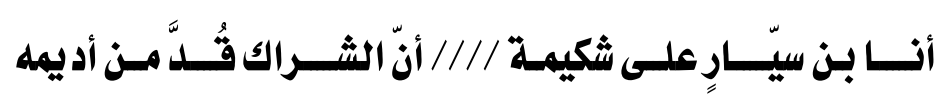

يفسر بعض معاني الراجز بحديث عمر ين الخطاب- رضي الله عنه-

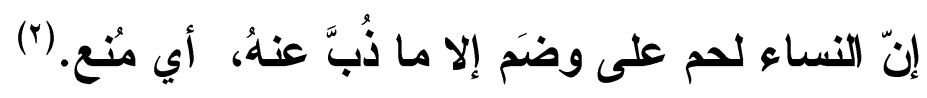

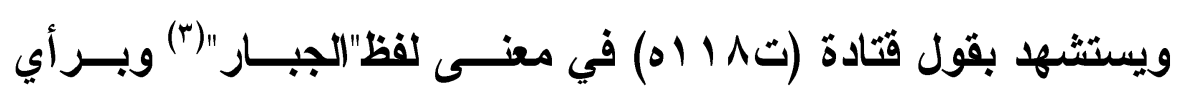

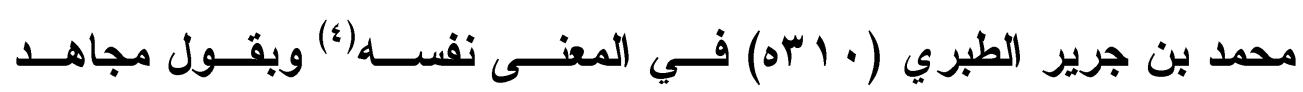

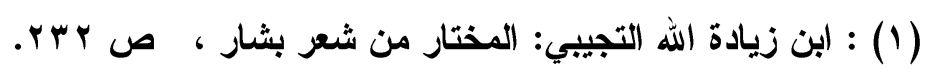

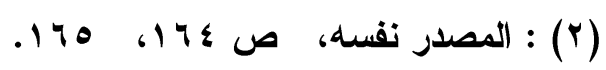

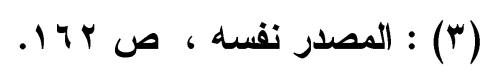
(ع) : المصدر نفسه، الصفحة نفسها. 


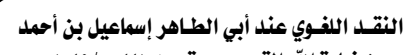

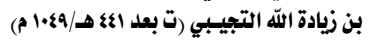
في كتابه (المختار من شعر بشار) اختيار الخالديين

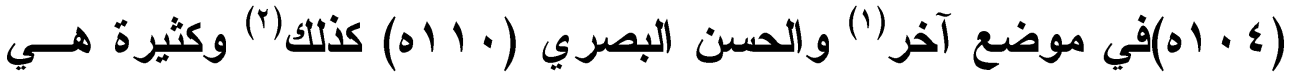

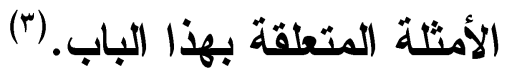

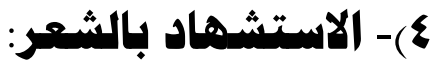

تعدّ النصوص و الثواهد الثعرية من الثوابــت فـــي تحديــــ ألفـــاظ

ودلالات نصوص شعرية أخرى، وكلما كانت الثواهد الثعرية سابقة لعصر بثشار بن برد زادت قوة الاستثهاد وصدقيته، وكأن "الاستثـــهاد بخطــاب

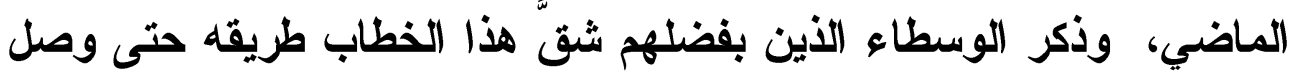

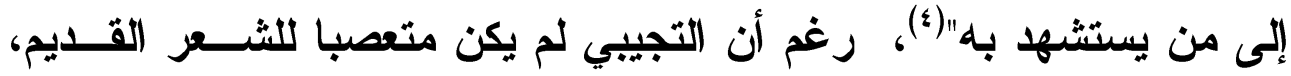

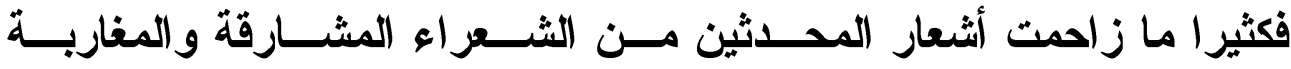
و الألدلسيين والصِّقليّين أثنعارَ القدماء وحازت صفحات عديدة من كتابه. وهذا هو منهج جميع الثرّاح في تاريخ الثروحات الثعرية العربية الطويل، حيث صارت "الثقافة الثعرية عندهم هي الحد الأدنــى لممارســة فئة

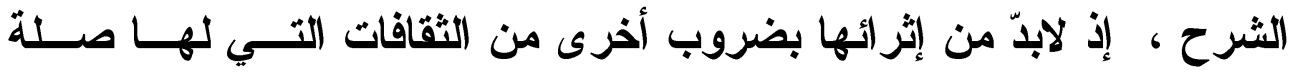

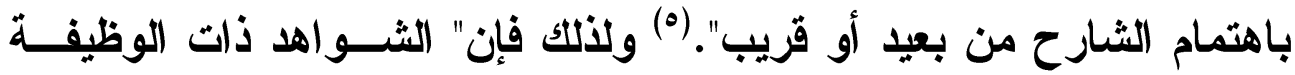
اللغوية هي بصفة عامة معينة للتاريخ على فهم النصوص الأصول، وتمثــل

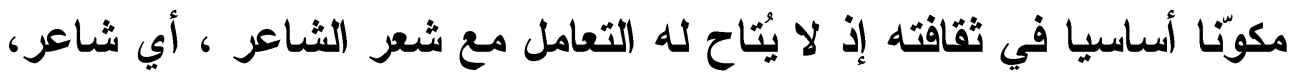

(1) : (المصدر نفسة، ص rol (1)

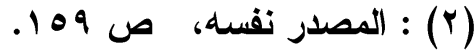

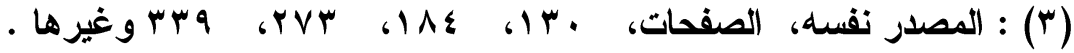

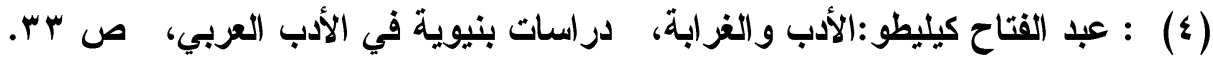

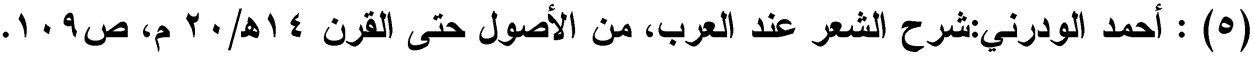


إلا إذا كان متمكنّا من نصوص شعراء آخرين قد يكونــون أضــرابا لـــلك

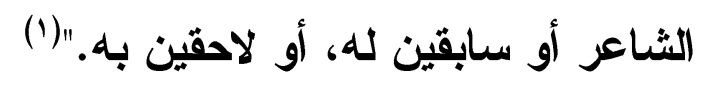

$$
\text { ففي ذكره لأبيات بشار بن برد الثهيرة: }
$$

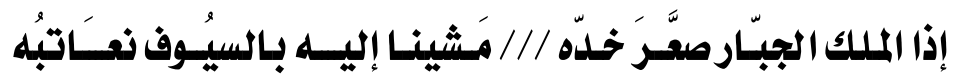

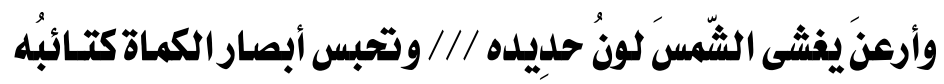

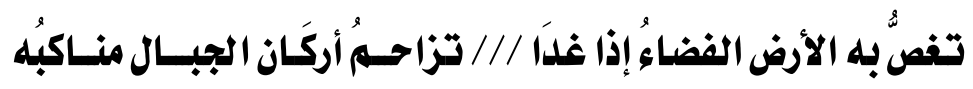

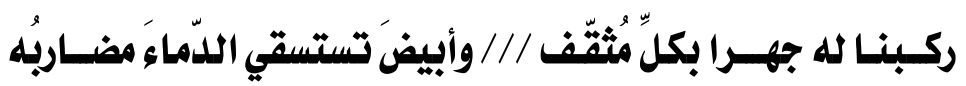

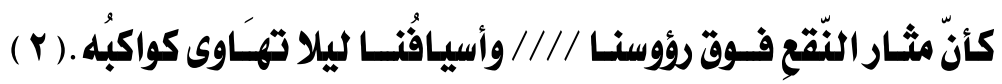

وبعد أن مضى الثشارح يستقصي أثثعار طائفة من الثــعراء مدّـن

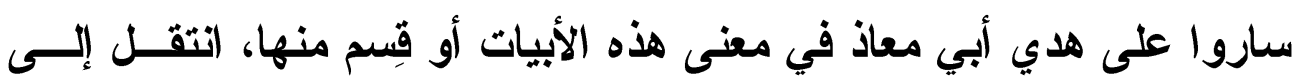

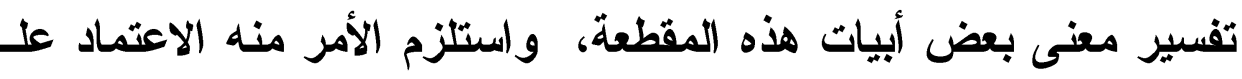

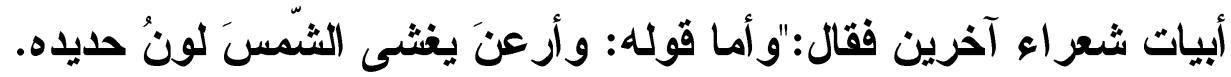
البيث و الأي يليه فمثلهما قول الثاعر:

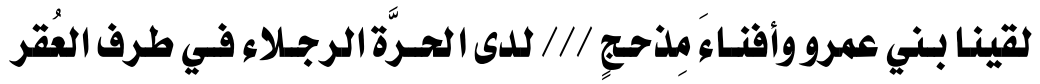
بجيش تضلّ البُلقُ في حجراته // / ويفشى شعاع الشمس بـالأنجم التُّهر

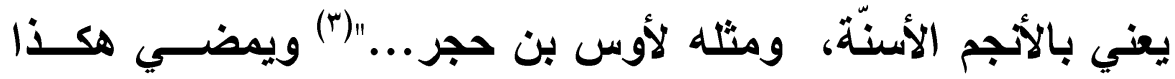

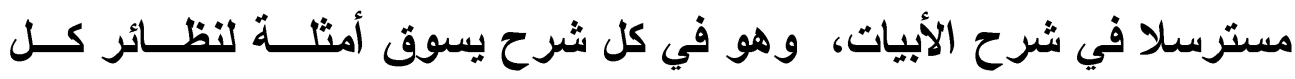
أبياته التي هو بصدد شرحها.

(1) : : المصدر نفسه، الصفحة نفسها.

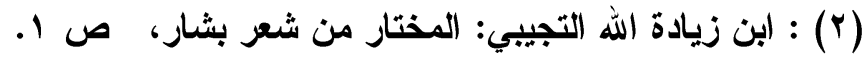

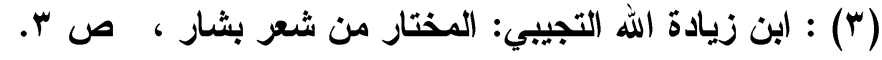




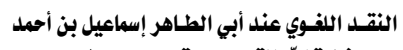

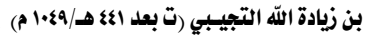
في كتابه (المختار من شعر بشار) اختيار الخالديين التين التين

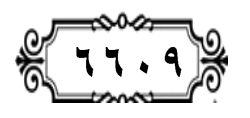

وقال في موضع آخر:"وقول أبي معاذ (بشار) من قصيدة:

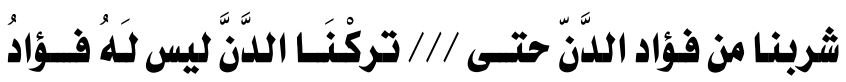

وليس الجسود منتحلا ولكن // على أعراقها تجري الجياد

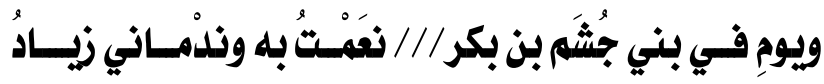

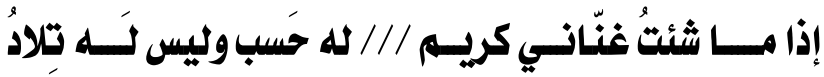

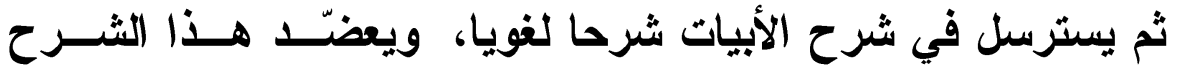

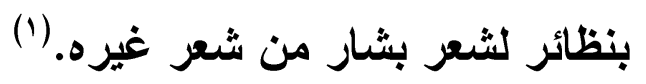

وقد يحدث وأن يفسر الثارح شعر بشار، ويجد له نظائر من شــر

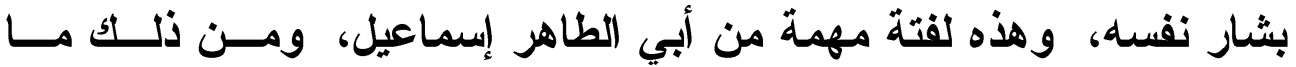
أورده من أبيات لأبي معاذ:

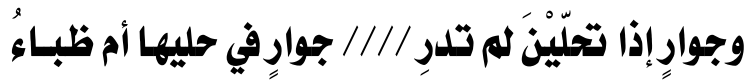

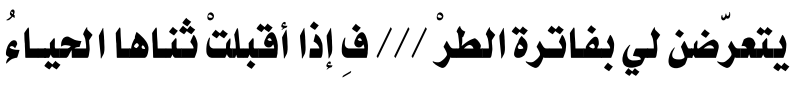

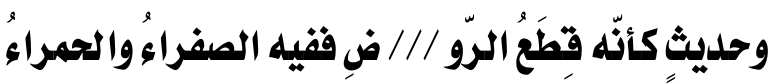

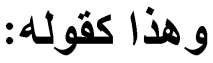

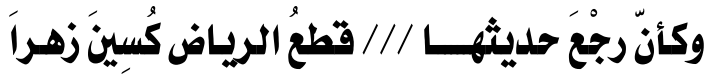

وكأزّ تحت لسانها / / / هاروتَ ينفُثُ فيه سـحراً

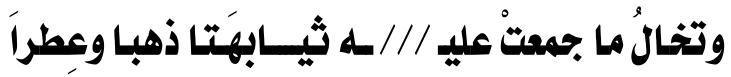

وذكر لله كذلك أبياتا أخرى بعد هذه الأبيات، و وكلها تفسير للمقطعـة

الأولى. (r)

وهكذا يجزي الشارح على هذا النسث في معظم أجزاء الكتاب.

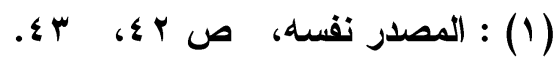

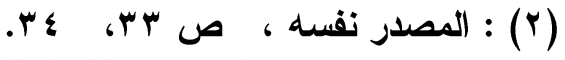




\section{0)- الاحتجاج بآراء اللغويين:}

قامت شروحات أبي الطاهر التجيبي لمختار ات الخالديين مــن شــر بشار على الار اسة اللغوية المستوسعة والمستفيضة.وهي ركيـزة أساسـية وأمر لا غنى عنه في فهم هذه الاختيارات الشعرية بشكل عام، فمن شـرح الألفاظ وتبيان الالامة العامة، وتفسير المعاني وذكر وجوههـــا المتعـددة، وتبَيُّن مواضع الإعراب من ذلك، وهذه هي الخطوة الأولى للنقد الأدبي في الارس النقدي العربي القديم.

وهو يروم إلى تحقيق ذللك، إمّا مفسرا شارحا، أو مقوّمـــا للألفــاظ

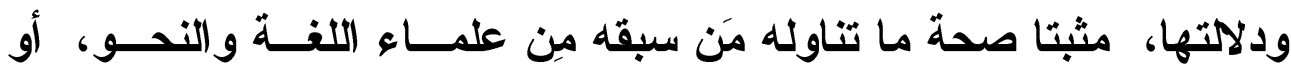
معارضا لألك مع الإتيان بالاليل في كلا الحالتين، وقد يعتمد في شــروحاته تلك على رأي واحد أو مجموعة آراو، وأحيانا أخرى يقدم تفسيرا أو شرحا لغويا من دون تحديد مصادره.وقد أعانه على ذللك سعة محصــوله اللغـوي ووفرة معارفه بدلاية الألفاظ وتر اكيبها. فكاتت شروحاته اللغوية وأحكامه النقدية في هذا المجال صادرة عن ثقافة موسوعية، مستندا في ذلك راجعا إلى أصول عامة يطمئن إليها الناقد

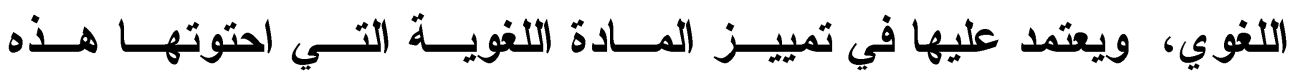

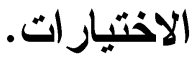

هذه الأصول اللغوية هي ما تعارف عليه العرب وتواضعوا، و وأقرَّها علماء اللغة وجعلوها قواعد وقوانين وأصول يَتنكم إليها كل ناقد لغوي، أو كل ناقد بشكل عام يستخدم هذه الأداة الإجرائية في تقويمه للنصوص الأدبية (نثرية أو شعرية).وكل ذلاك له ما يبرّزه فقد " لعبث هذه الفئة من اللغــويين 


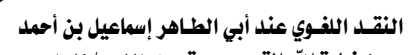

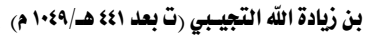

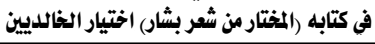

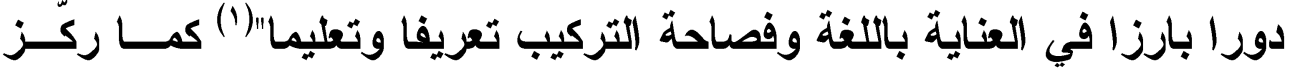

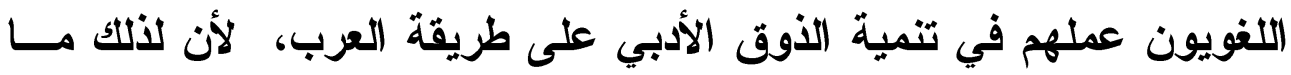

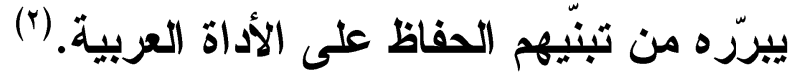

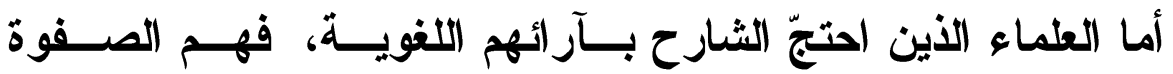

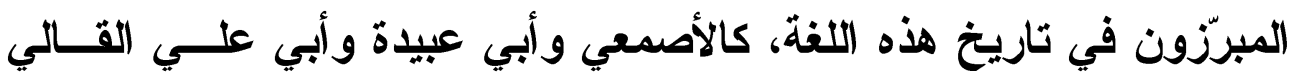

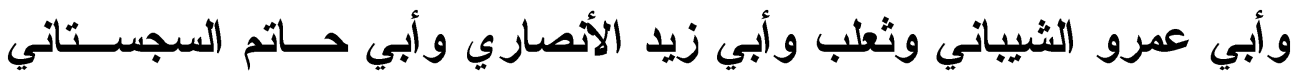
و الزجاجي والأخفش و الزجّاج وغيرهم من الفطاحل. فقي ذكره لمقطعة من شعر بشار منها:

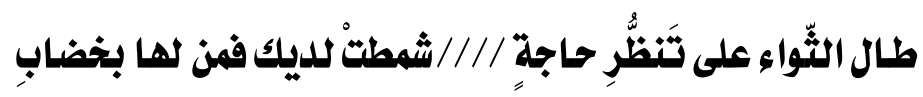

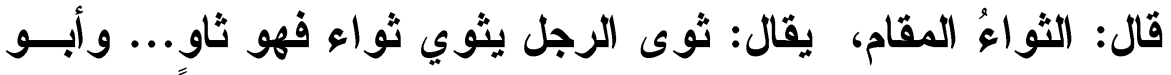

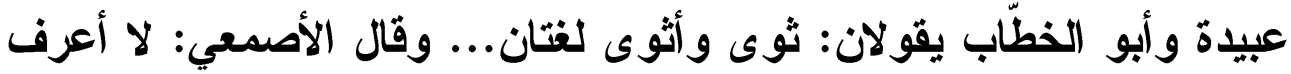
إلا ثوى يثوي، وأنكر أثوى. (ז) ويقول في موضع آخر: وفي الحيّة لغتان عرِبْــــــــالتخفيف بكسـر

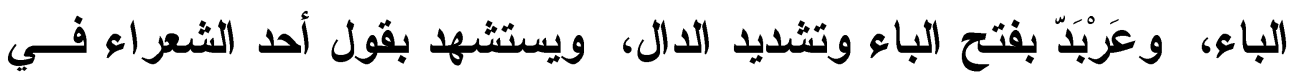

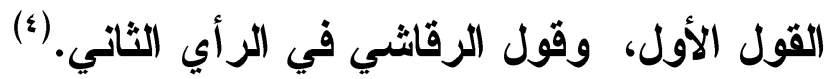
ويستمر في عرض مختلف الآراء حول مواد لغوية مختلفة. (0)

(1) : مصطفى عليان عبد الرحيم:تيارات النقا الأدبي في الأدلس في القرن الخامس الهجري،

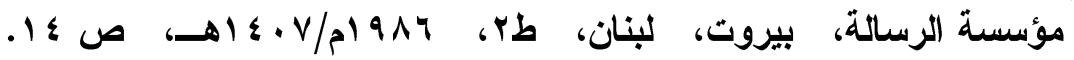

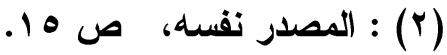

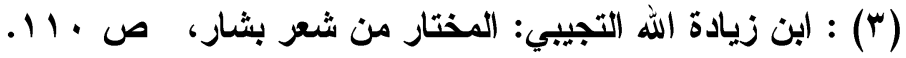

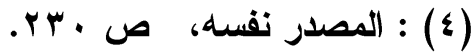

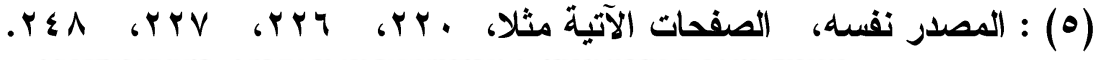


وقد يذكر رأيين مختلفين ويفاضل بينهما، كما حصل في مفاضلته بين

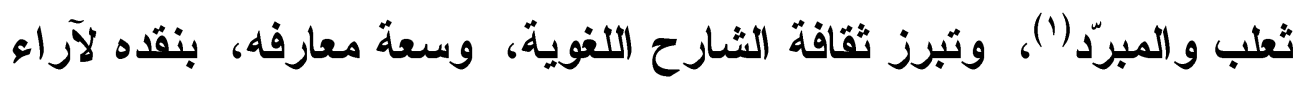

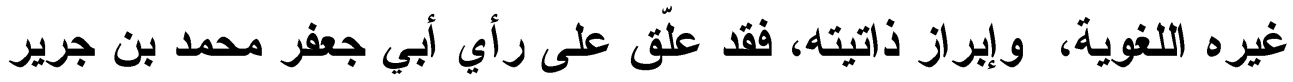

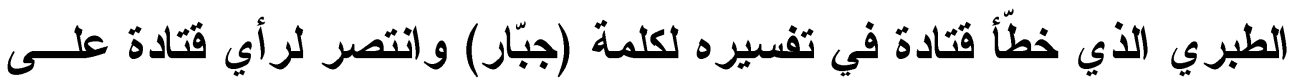

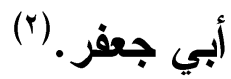

وقد طرح أبو الطاهر إسماعيل بن زيادة الله التجيبي قضــية مهمــة

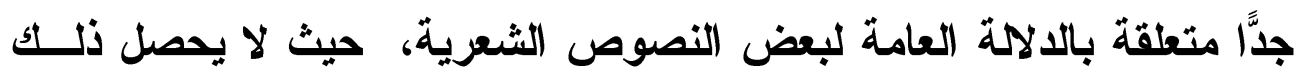
إلا بالتوقيف، فقي ذكره لقول الثاعر:

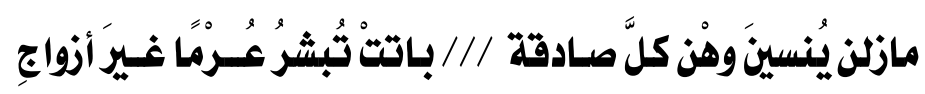

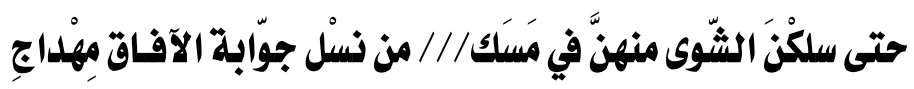

قال :"هذان بيتا معنى لا تعرفه إلا بالتوقيف، و وتفسيرهما علـى مـــا

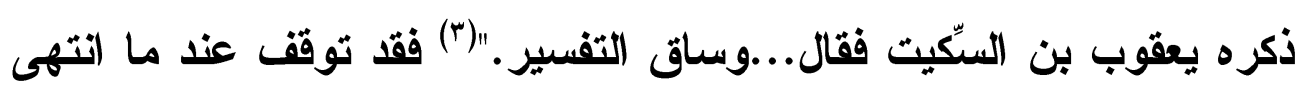

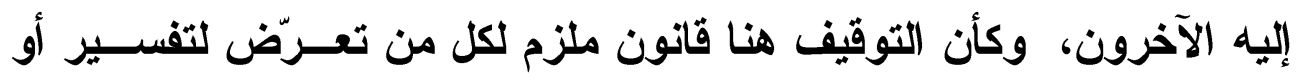
شرح هذه اللغة.

وهو ربما في استعراضــه لآراء علمــاء اللغــة وذكــر مرجعياتــهـ

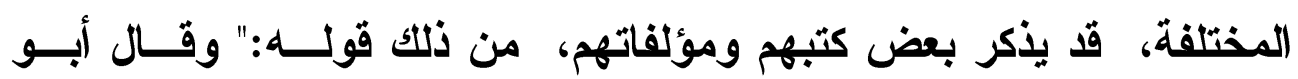

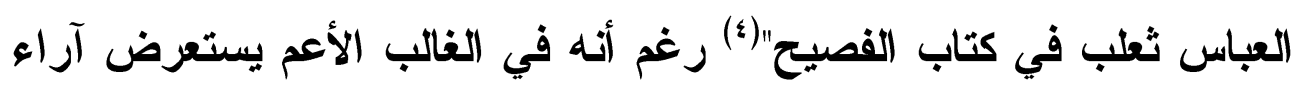

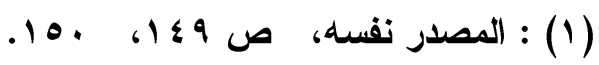

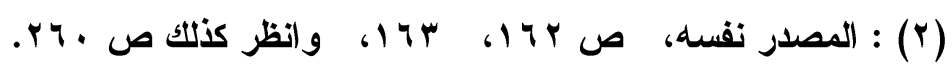

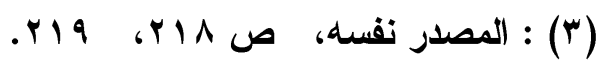

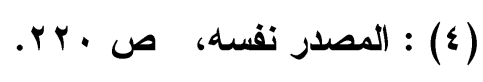




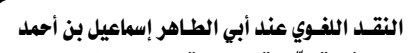

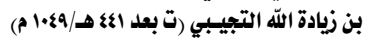
في كتابه (المختار من شعر بشار) اختيار الخالديين

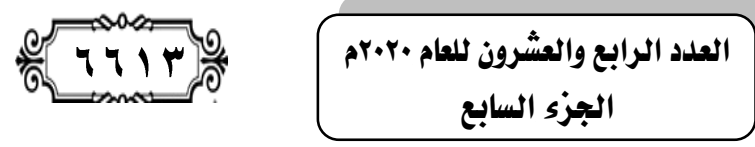

الغير من دون تحديد مصادر آرائهم وأقوالهم.وقد تزول الإحالة فــي ذهــر

بعض شروحاته اللغوية، مثل قوله:"ويقال" وغيرها من الصيغ الأخرى. (')

\section{1)- نقد الرواية وتوثيق النصوص:}

استغرق كتاب التجيبي " المختار من شعر بشار، اختيار الخالــديين"

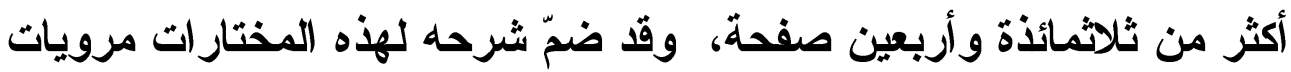
عديدة شعرية ونثرية وآراء لغوية ونحوية وصرفية وأخبار شتى.

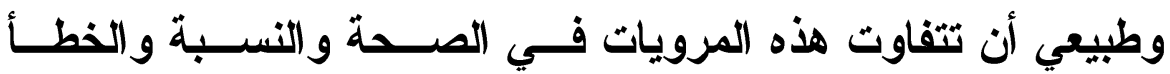

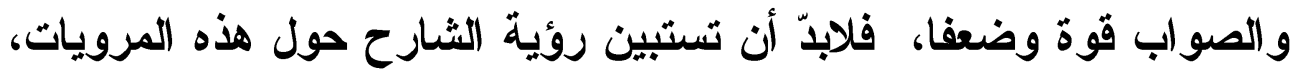

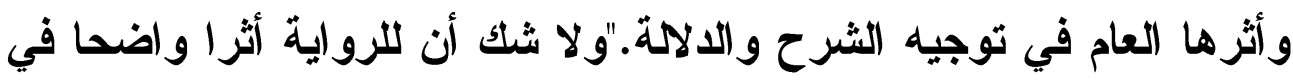

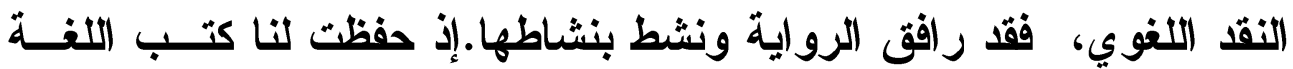
والأدب ألوانا منه لم تكن لتظهر لو لا لا الرواية". (†)

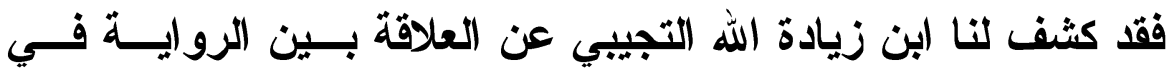
تأرجحها بين الثكتّ والإثبات وأثر ذلك في استيضاح معنى النص.

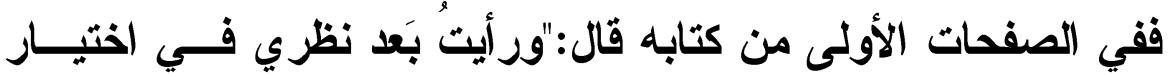
الخالايين وما اخترته منه شعرا منسوبا إلى بثار فيه من هذه الأبيات أبيات

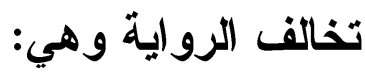

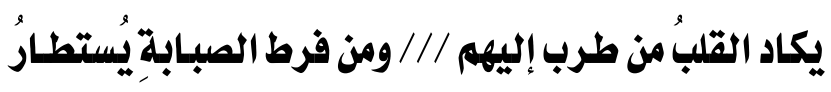

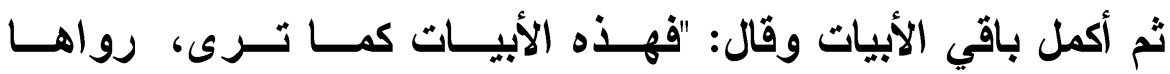

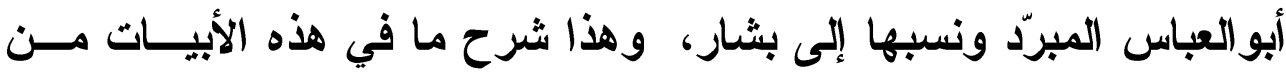

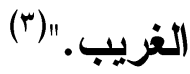

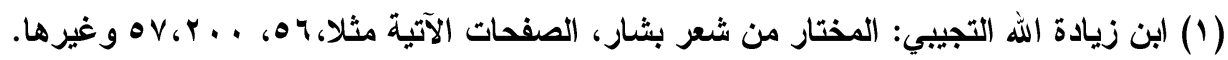

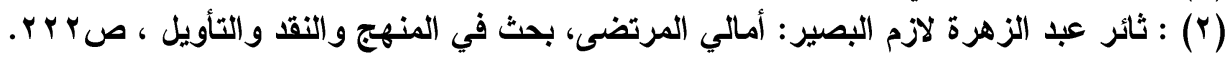

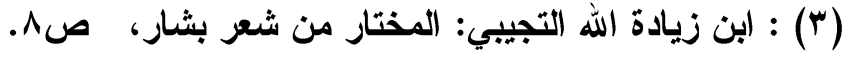


وذكر في موضع آخر من الكتاب أبياتا ليشار بن برد:

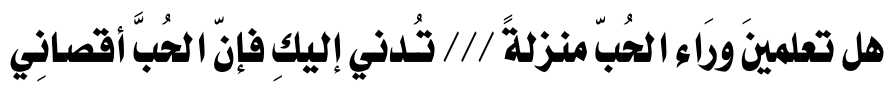
ثم استرسل في ذكر باقي الأبيات، وقال:"أمّا البيث الأول مــن هـــه الأبيات فليس لبشّار وإنما استعاره وينى عليه سائر أبياته، وهو ليعقوب بن البن عبد الرحمن المخزومي، وقد ادّعاه أيضا غيره."(1) وقد فاضل إسماعيل بن زيادة الله في موضع آخر من الكتــاب بـين بعض أبيات بشار بن برد وأبياتا للبيد فقال: وأتمّ من بيت بشار معنى وأبين شرحا قول لبيد بن ربيعة:

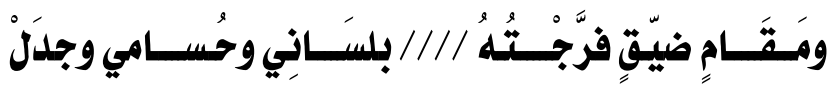 لويقوم الفيلُ أو فيَّــالُه //// زلَّ عن مثـل مقامي وزَحلْ}

ثم يقول:" هكذا وجدت بيت لبيد كما كتبته - بلساني وحسامي وجدل

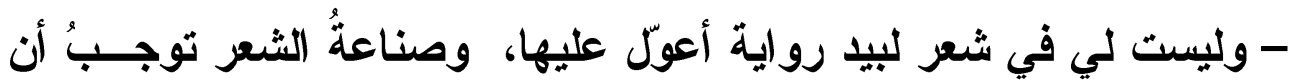
يكون.بسناني وحسامي، ليزيد المعنى بذكر السنان ولئلا يتكرر؛ لأنَ قولــهـ وجل يغني عن ذكر اللسان إذ لا يكون الجدل إلا به. (؟)

\)- الثقافة البيئية ( ثقافة المجتهع العربي) ودورها في التفسير اللغوي: كان أبو الطاهر إسماعيل التجيبي مدركا بأن " الــص لــه مــلول ثقافي"(ז) وبأن النصوص الشعرية ومختلف الشواهد والمختار ات لا يمكن بها

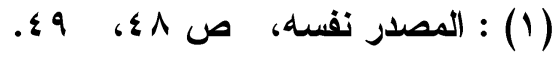

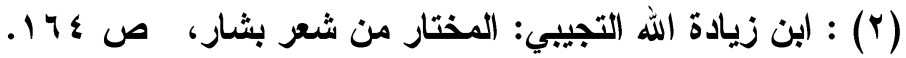

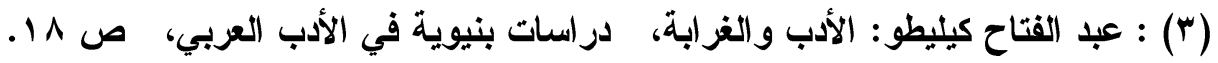




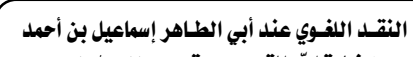

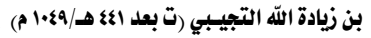
في كتابه (المختار من شعر بشار) اختيار الخالديين

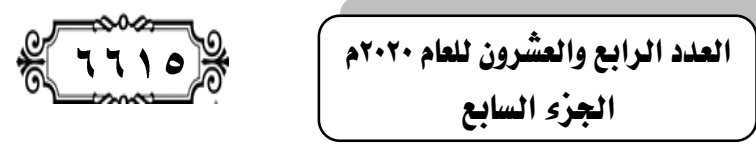

أن تنفصل عن السياق العام الأي نشأت فيه؛حيث يلعب هــا الســياق دورا مهما في توجيه المعنى العام للنص.

إن" الثارح وفي ممارسته للنقد اللغوي وفي شرح النصوص بالطرق المختلفة يدرك أن هذه الممارسة النقاية وحدها قاصرة مالم تستند إلى ثثافة عامة تاريخية، أو محيطة بسياق تلك المختارات الشعرية من شعر أبي معاذ إنهاد

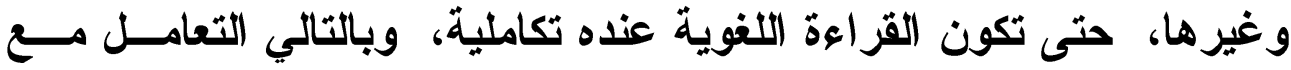
الثواهد و النصوص أو الاختيار ات بثكل أوسع. لقد أسهم التجيبي في سبيل فهم أعمق وأدق للمختـــارات الثـــرية، في تنزيل هذه النصوص المشروحة والتي اختارها الخالديان، ضمن شــبكة

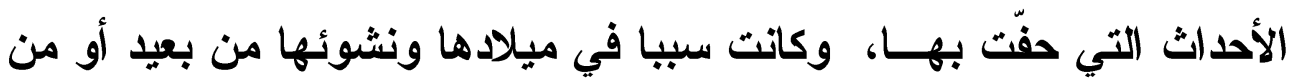

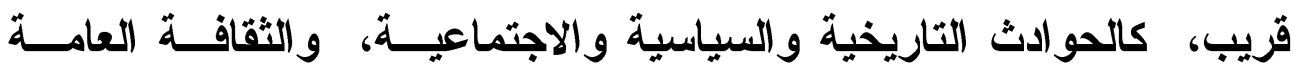

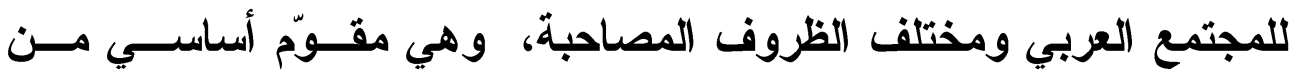
مقوّمات النقل الحديث، ما يجعل تفسيره أكثر وضوحا وتقويمه أكثر دقة.

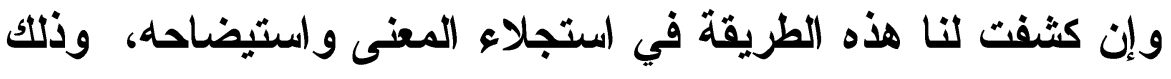
بتبيان الظروف التي أسهمت في خلق النص، فإنها من وجه آخر كثفت لناء لناء ثُقافة الثارح و بُعد نظرته نحو مقصدية النصوص.

وفي هذا الإطار يقول أحد الباحثين:"إن الاحتفاء برصد أحـداث لهــا

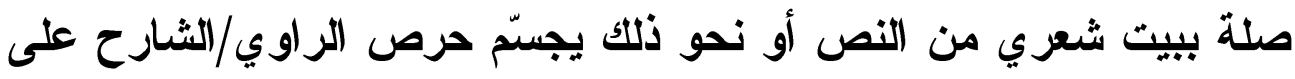

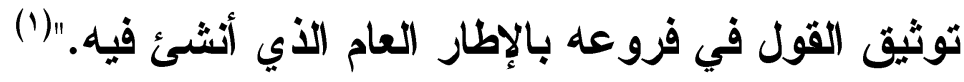

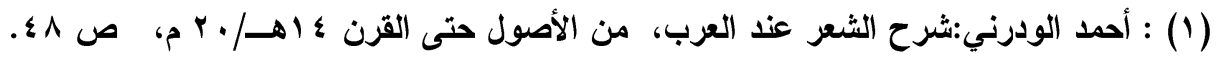




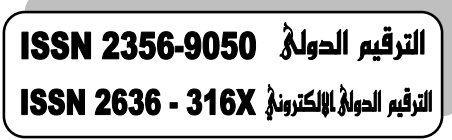

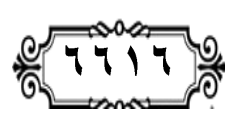

حولية كلية اللغة العربية بجرجا مجية مجلة علمية محكمة

وفـي هذا الصدد يمكن أن نقول "إن المقام ينهض على عـــة أطــر

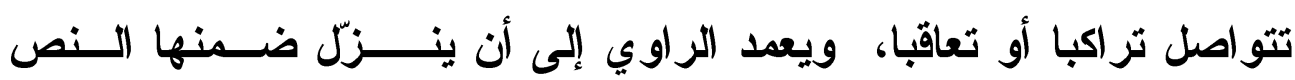

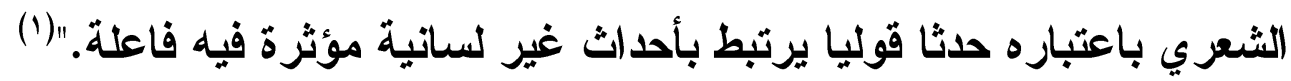

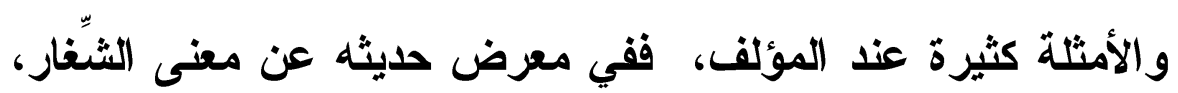

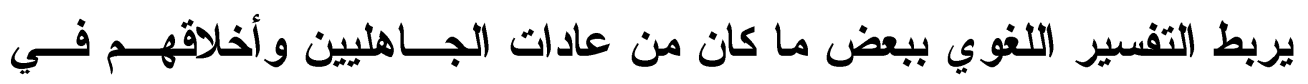

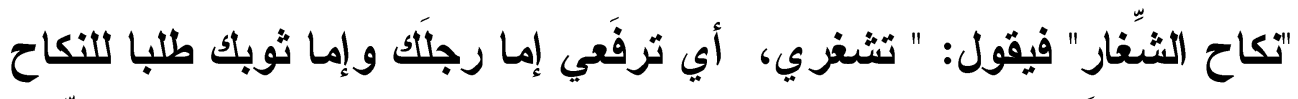

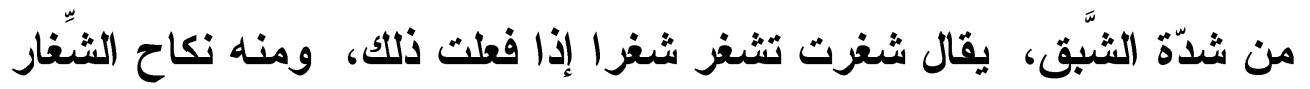

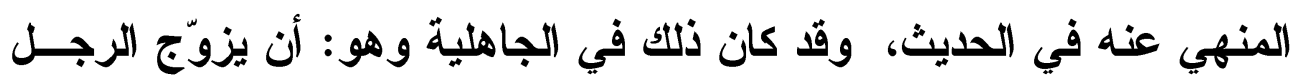

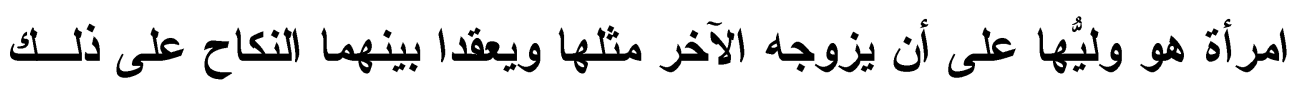

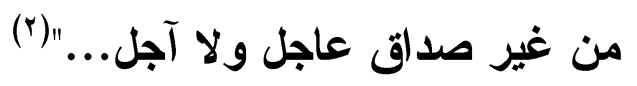

وفي موضع آخر من الكتاب وفي تفسيره لمادة (عذل) قال:" العــذل

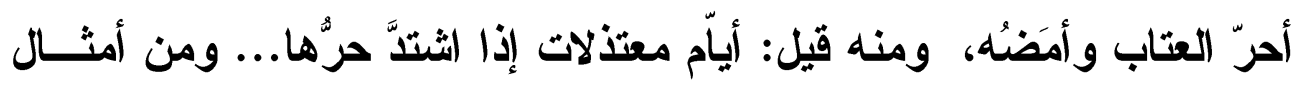

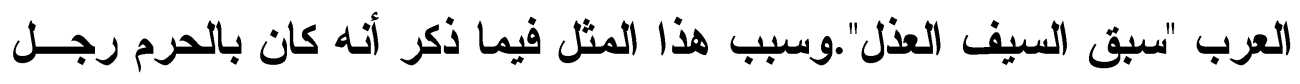

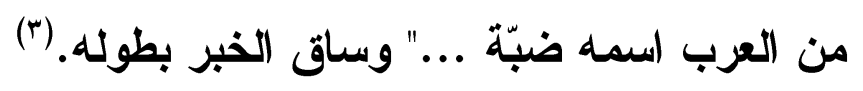
ويمضي المؤلف على هذه السبيل في اســتجلاء معــاني النصــوص وردّها إلى السياق العام الأي نشأت فيه، ويذكر في بعض شئل فروحاته اللغوية

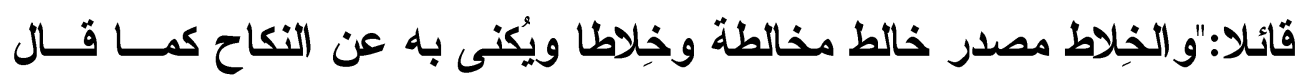

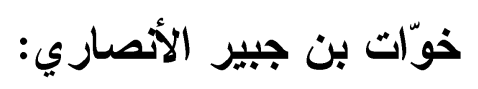

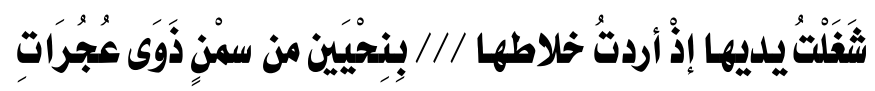

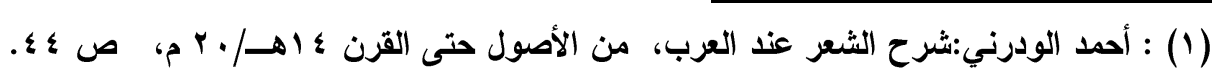

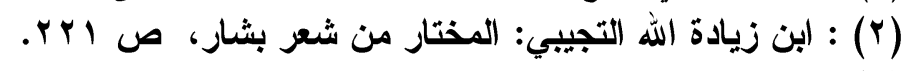

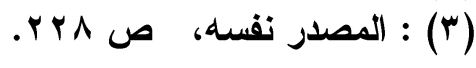




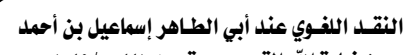

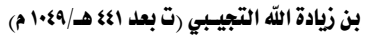
في كتابه (المختار من شعر بشار) اختيار الخالديين التين التين

وهذا يقوله خوّات لذات النحيين وهي امر أة من تيم اللاّت من ثُعلبـة

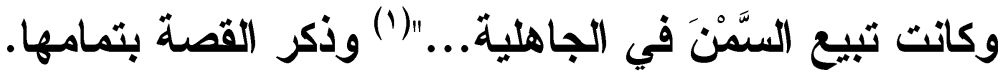

وتجده في مواضع أخرى من الكتاب يستعرض بعض الأخبـــار التــي

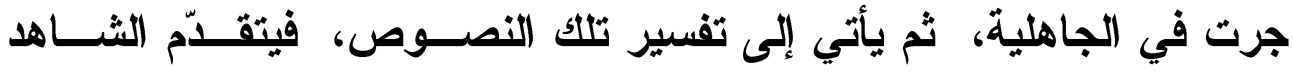

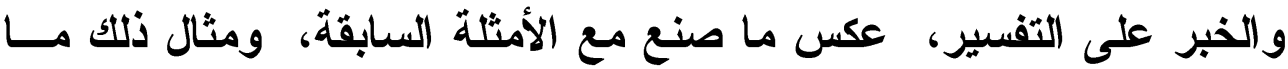

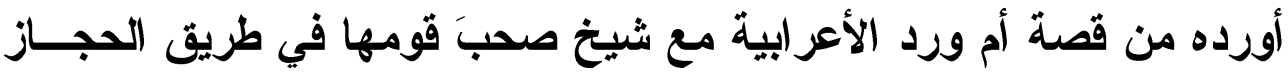

وكانت فيهم... (r)

وقد يسلك المؤلف درب الأسطورة سبيلا إلى صوغ تفسـير لغــوي

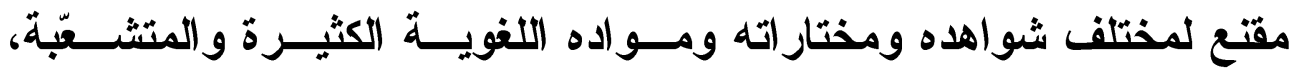

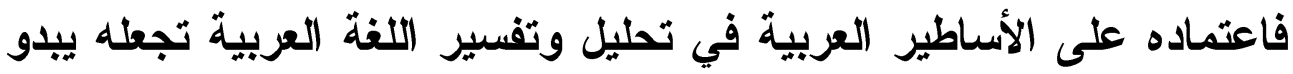

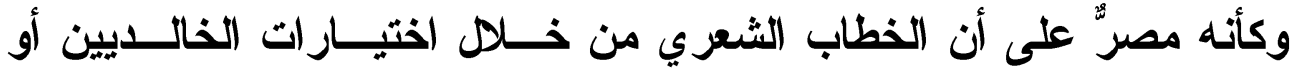
مــتاراته هو - بوصفه خطابا أدبيا- لا يـــكن فهمه بمعزل عن الخطابات

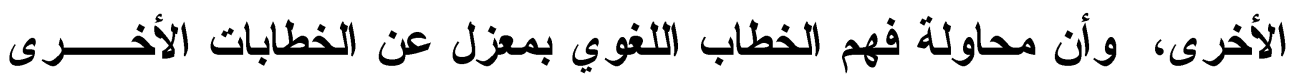
أو الثقافة التي احتضنته هو محاولة مبتورة، مشينة للمعنى.

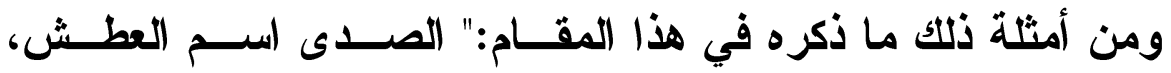

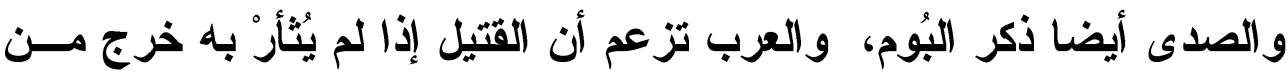

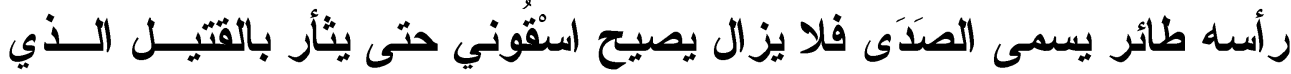

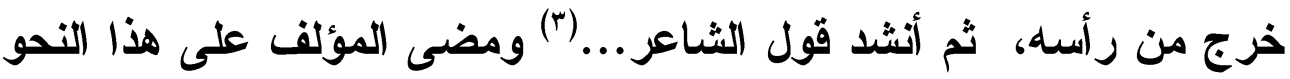

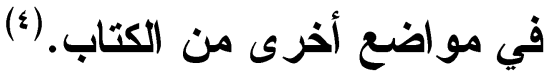

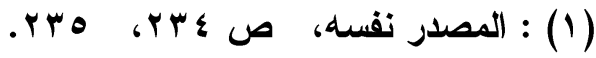

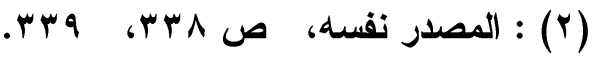

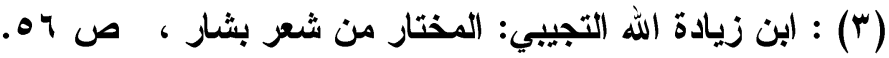

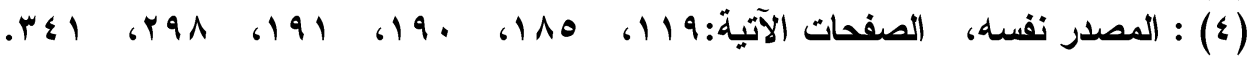




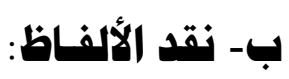

تشكل اللغة أهمية كبرى في حياة الإسان فهي أداة تواصل ووعــاء

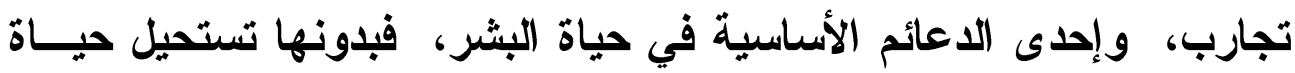

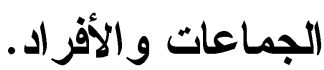

كما أن" اللغة قوام الأدب وعنوان وجوده، وإذا كانت اللغة تكثـفـ

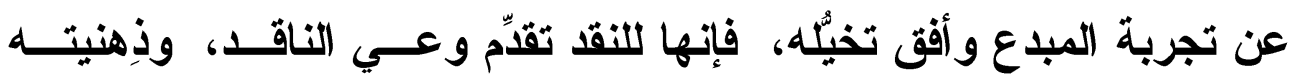
ومستوى معالجته و انتمائه وحدود موقعه" (1"). وعلى هذا الأساس فقد" نثأ العربي في ثقافة ترى إلى اللغة بوصفها

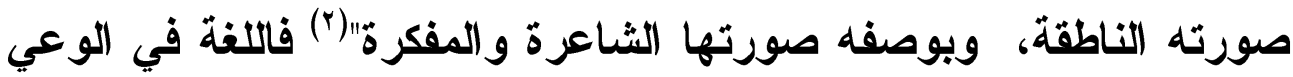
العربي الأصلي، تبدو وكأنها الكائن نفسه، و ويبدو علمها علم الكائن.(r)

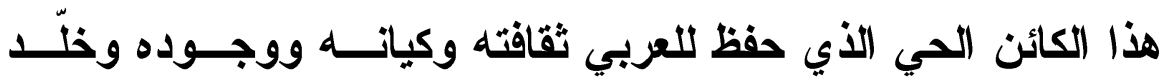

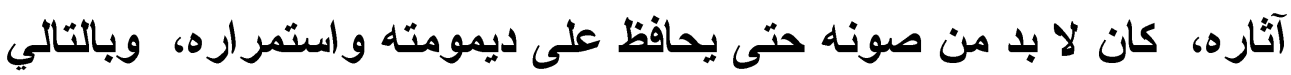

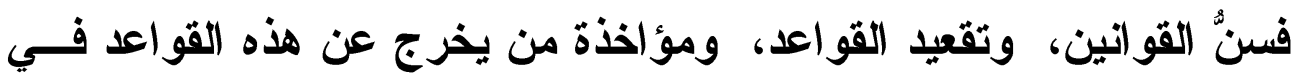

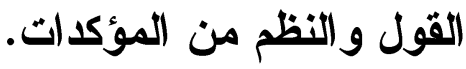

و إذا كان" النص الأدبي قدرة متحققة تُشتعمل فيـــه اللغـــة اســتعمالا

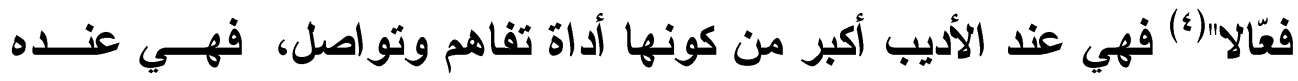

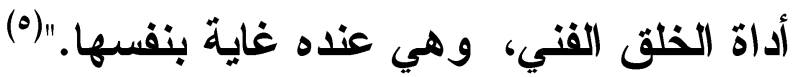
(1) :عبد السلام محمد رشيد: لغة النقل العربي الققيم بين المعيارية والوصفية حتى نهاية القــرن

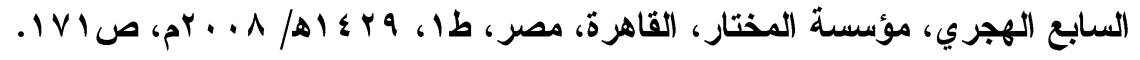

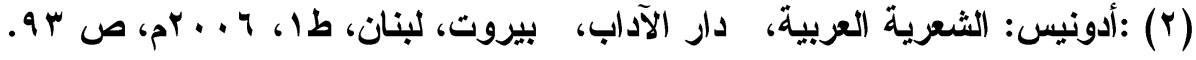

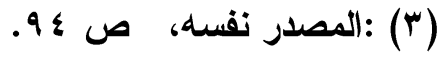

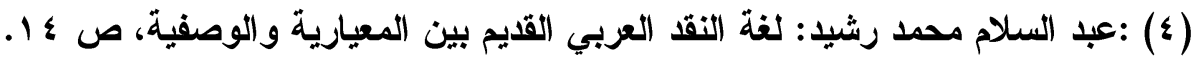

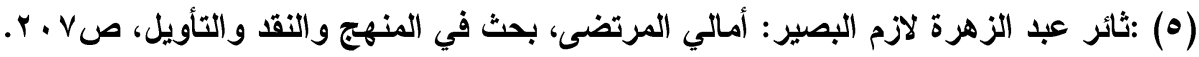


و إذا كاتت اللفة عند الأديب أداة الخلق الفني، فهي عند الناقد" لغــة

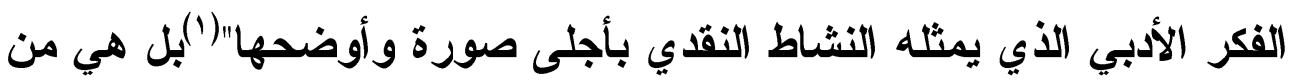

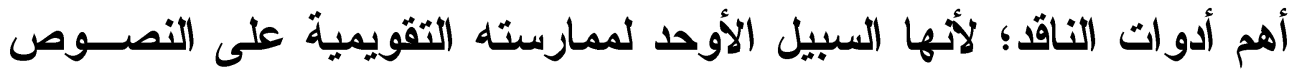
الإبداعية، كما أنها المصدر الأساسي لاراسة الناقد وسلامة أحكامه.

ومعرفة الألفاظ، غريبها وحُوشيها، ودقائق معانيها، مما يحتاجسهـ كل ناقد حصيف، خاصة عندما يتناول شعر القـــماء وإبـــاعاتهم، حيــث تزدحم الألفاظ الغريبة، والمعاني المستغلة، وريما الكلمات المستعصـية،

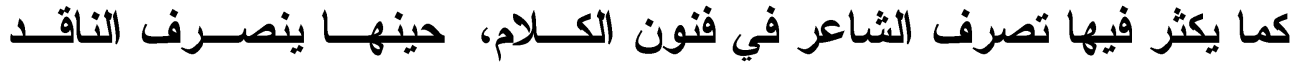

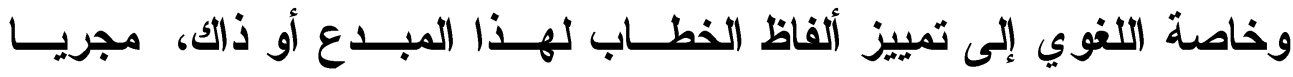

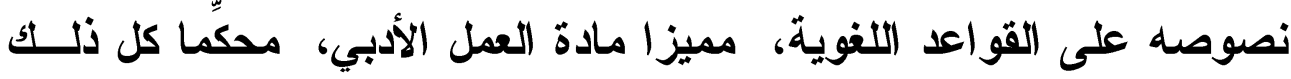

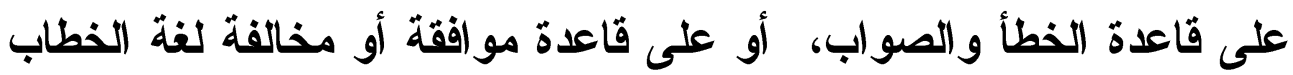
الإبداعي لسنن العرب في كلامها.

ولكن يجب أن يقرر الناقد إلى جوانب القوانين والقواعد التي يجُري عليها أحكامه بالنسبة للنصوص الأدبية" فالظاهرة الأدبية مادة لغوية أساسا،

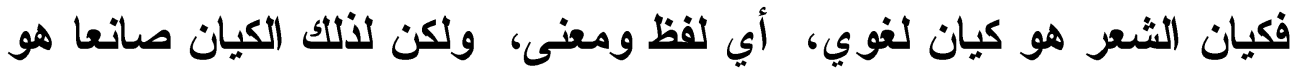

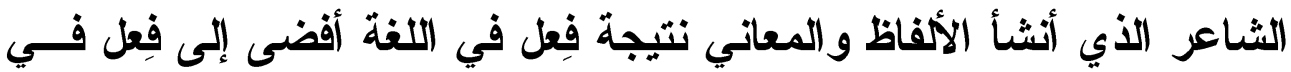

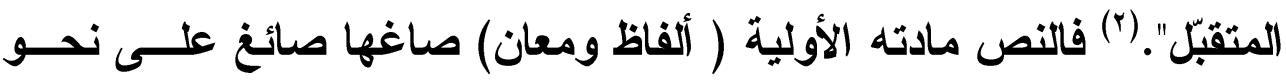

ما. (r)

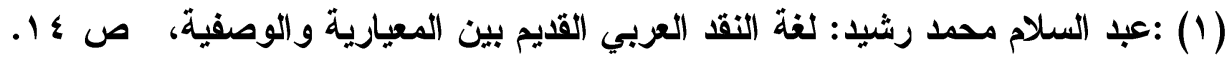
(Y) :أحمد الودرني: قضية اللفظ والمعنى ونظرية الثعر عند العرب من الأصول إلــى القــرن

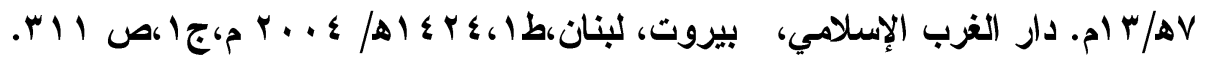

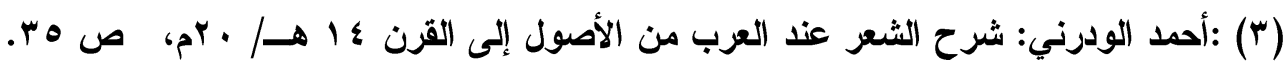


وأي صائغ في هذه المختارات التي شرحها أبو الطــاهر إبــــاعيل

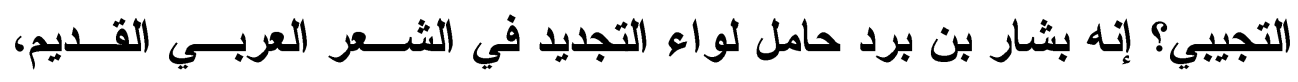

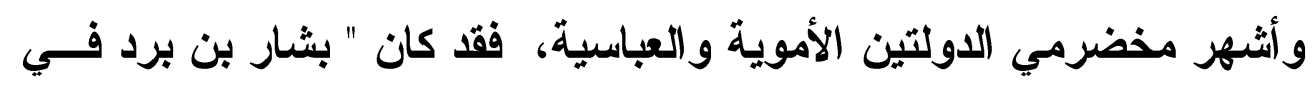

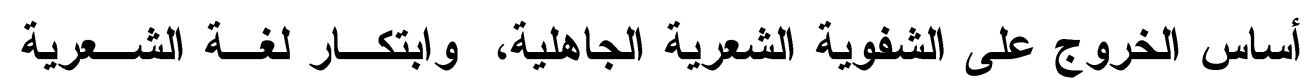

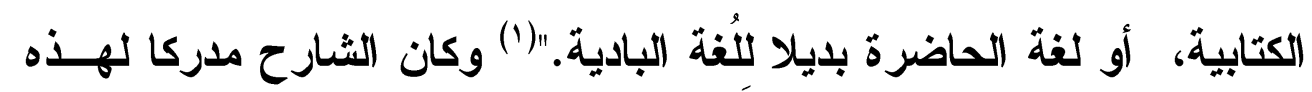

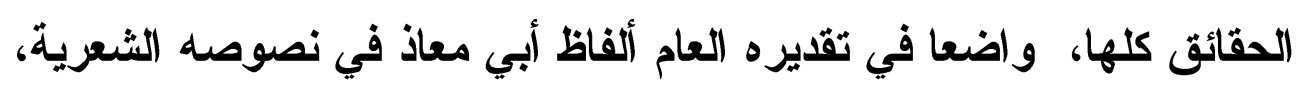

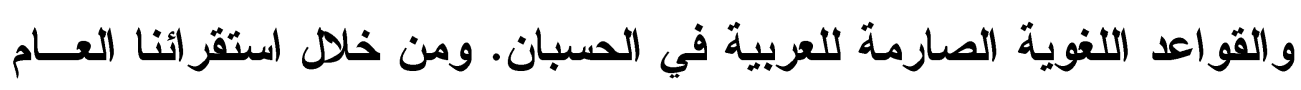

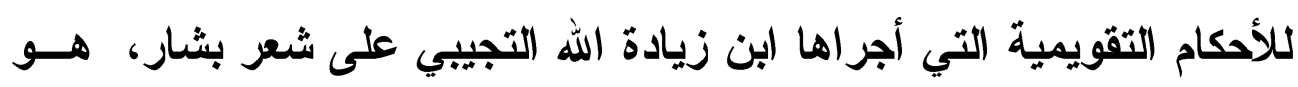

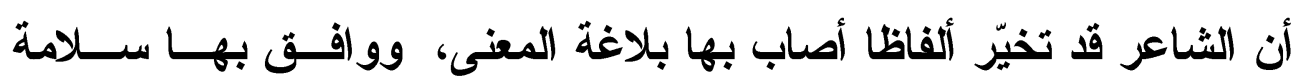

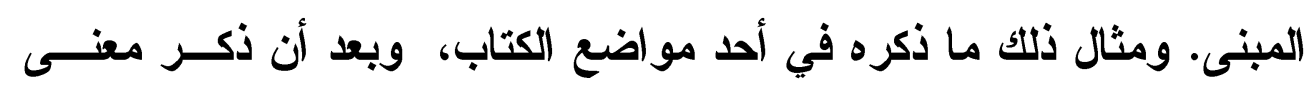

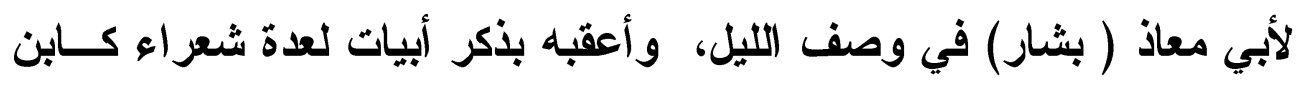

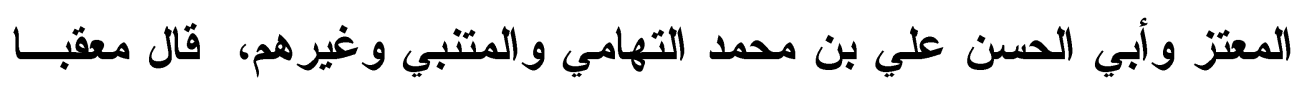

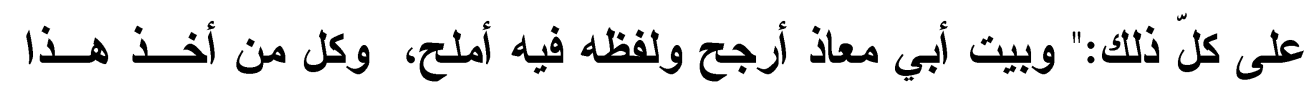

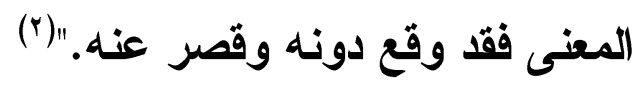

ويجري الثارح أحكامه في قضية اللفظ على أساس الدقة في اختيار اللفظ من قبل الثاعر ومدى الاتفاق أو التناسب الحاصل بين اللفظ ومعنــاه

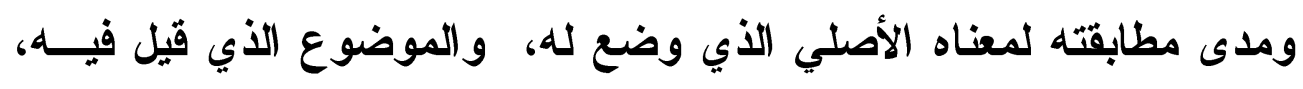

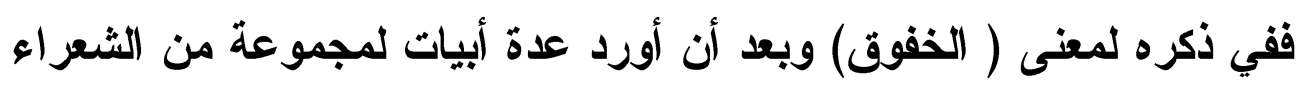

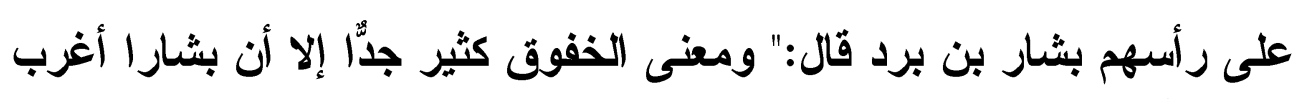

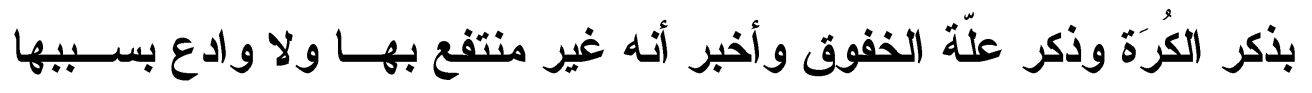

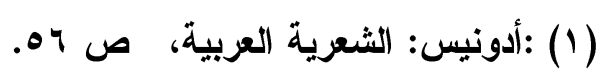

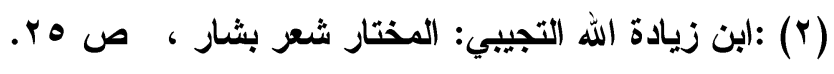




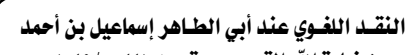

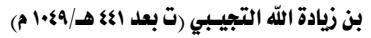
في كتابه (المختار من شعر بشار) اختيار الخالديين

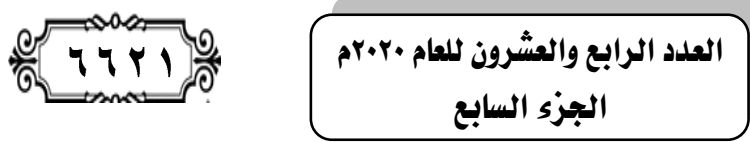

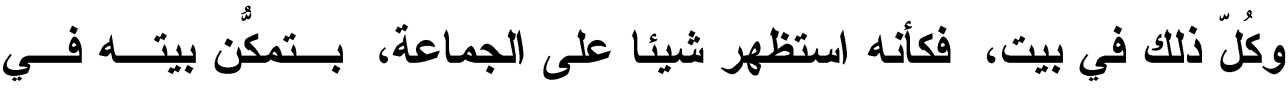

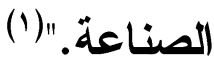

أما مناسبة الألفاظ لمعانيها ومشاكلتها إياها فمِن أوكَِ القو اعد عنده

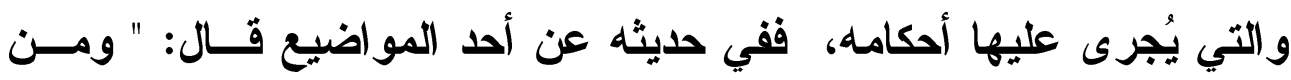

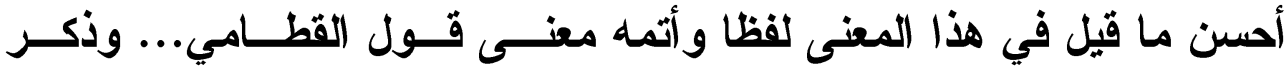

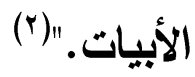

أما تلخيص المعاني بأحسن الألفاظ وتهذيبها فهو من الثوابت التــي

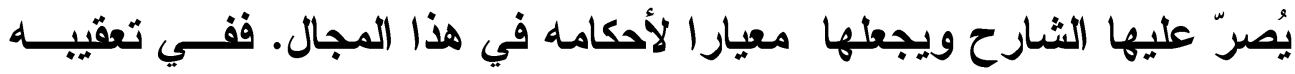

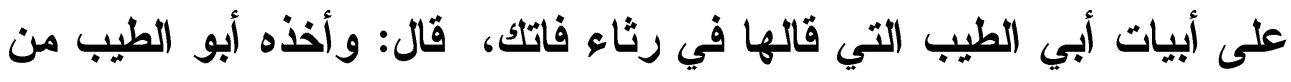

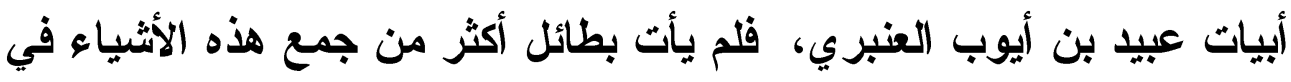

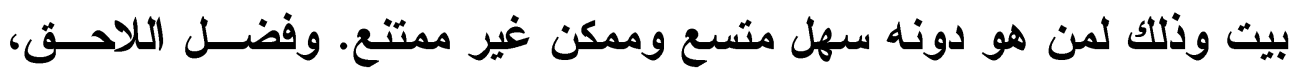

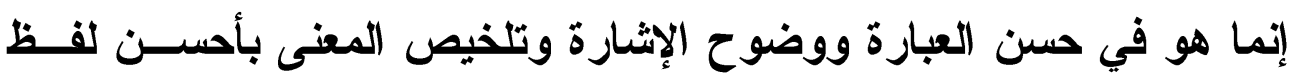

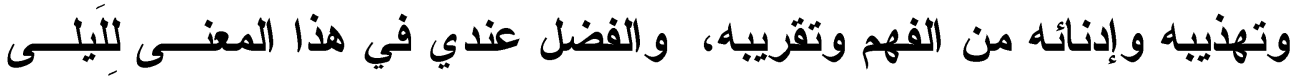

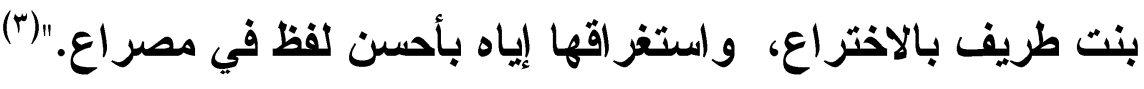
واختصار اللفظ لعديد المعاني من المسلمات التي يعتقــها الثـــارح

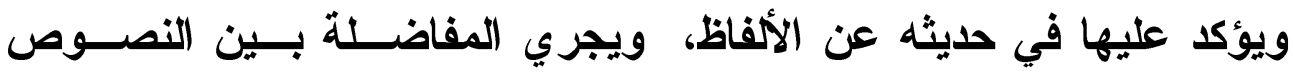
الشعرية على هذا الأسناس.

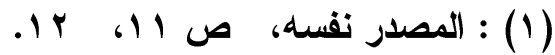

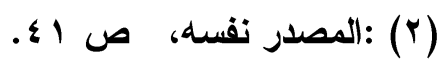

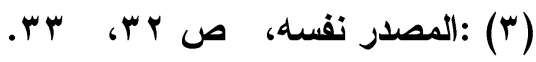


ومن ذلك إير اده لبعض أبيات بثار بن برد في قصيدة وهي من جيد

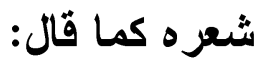

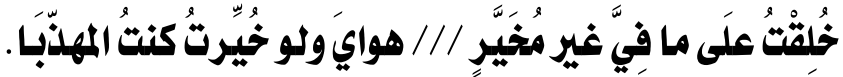

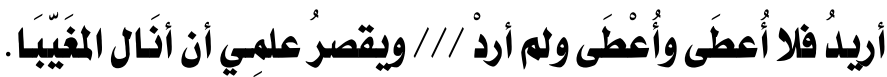

وأكمل باقي الأبيات، ثم قال: المهذب الكامل الأخلاق المصفّى الثيم

من شوائب النقص قال النابغة:

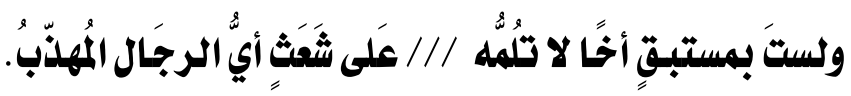

مثل بيت النابغة هذا لفظا ومعنى قول الآخر :

ولستَ بمستبقِ صليقا ولا أخ // / إذا لم تَعَدّ الشيء وهويريبُ.

إلا أن بيت النابغة أفضل؛ لاختصار لفظه وزيادة معناه على هذا..."(')

وفي الموضوع نفسه يورد أبياتا لأبي معاذ من قصيدة طويلة منها:

$$
\text { فتى لا ينام على دمنةٍ // / ولايشرب بالماء إلا بلدم }
$$

فقد أورد شرحا طويلا لهذه الأبيات وما يجري على نسقها ثم قــال:

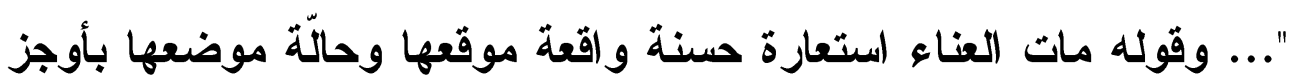

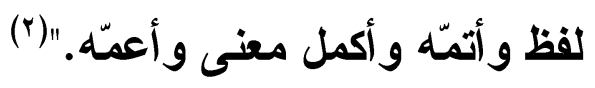

(1) : (بن زيادة الله التجيبي: المختار من شعار بشار، ص ص111.

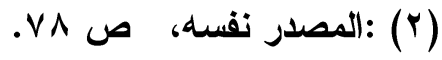




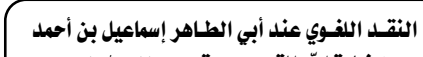

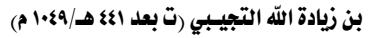
في كتابه (المختار من شعر بشار) اختيار الخالديين

\section{كما تحلث في مواضع أخرى من الكتاب عن " عذوبة اللفــظ وقـوة}

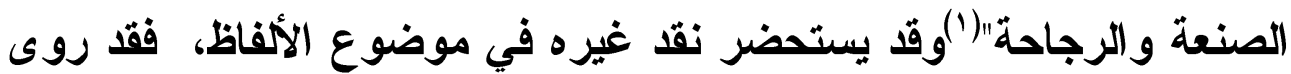

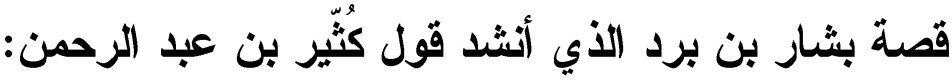

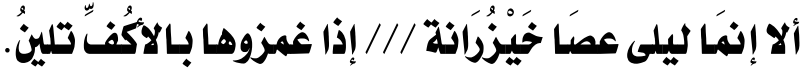

فقال: ما لأبي صخر قاتله الله يزعم أنها عصا ويعتذر أنها خيزرانـــة

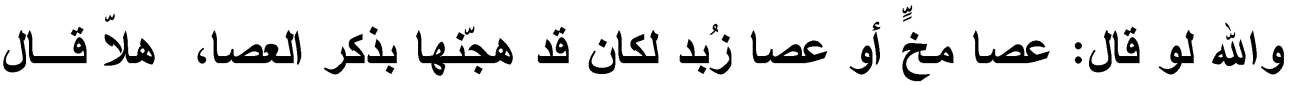
كما قلت وأنثد - وحور اء المدامع من معد - و البيت الأي بعده(†). وهكذا يمضي الثشارح فـــي تقصّـيه لقضــية الألفــاظ وســلامتها، ومشاكلتها لمعاينها، أو اختصارها لمجموعة من المعساني المتعـددة مــع عذوبتها، على هذا النسق في شروحاته كلها، وهي خطوة مهمة وصـائبة من خطوات النقا اللغوي. ج- نقد المعاني: - ( لا يحسن الحايث عن القواعد التي تقِيم اللفــظ دون الحــيث عـن المعاني، فكلاهما وجهان لعملة واحدة ، فبتشاكلهما تكتمل الدلالة العامــة للنصوص الأدبية شعرية كانت أو نثرية. وبعض النقاد يغالي فـي تقــديس المغنى وإضفاء هالة عليه، ومن هؤلاء عبد القاهر الجرجاني الأي يقول:"

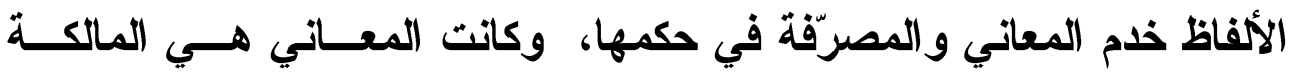

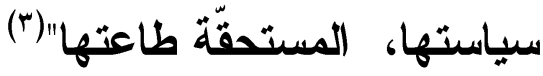

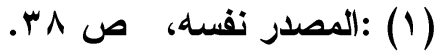

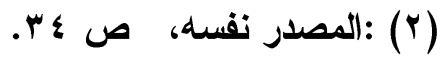

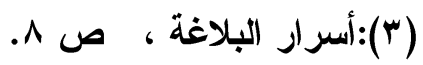


وعلى أسساس ضبط المعاني ووضوحها وعدم خروج الثــاعر عـن القواعد النحوية والصرفية والأي يؤدي إلى فســاد المعنــى بشـــل عــام، فاللغويون عادة ما يعيبون الخروج عن القاعدة النحوية أو الصرفية حتـى لـى

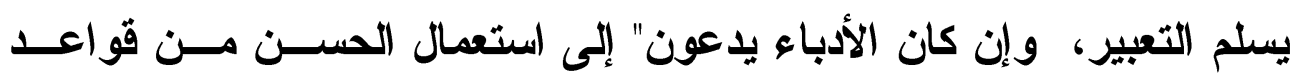
(النحو (مليح النحو)"(1)

وقد أجرى التجيبي أحكامه في شروحاته للشعر على أساسين همــا: النحو و الصوف.

\section{أولا: نقد النحو:}

اعتنى التجيبي بالنصوص الشعرية المتضمّنة في هذه الاختيار ات؛ أي

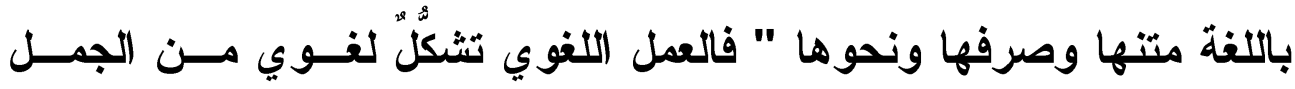

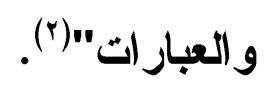

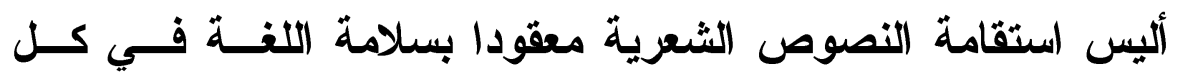
الأحوال؟ فالنحو في الكلام كالملح في الطعام، إذ المعنى أن الملام لا يستقيم ولا تحصل منافعه التي هي الالالات على المقاصد، الا بمر اعاة أحكام النحو

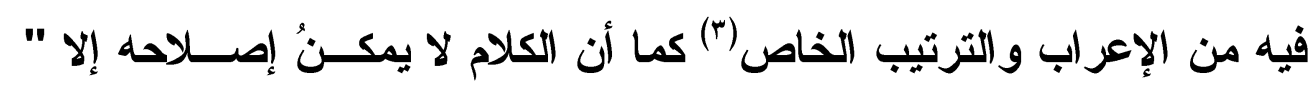
بإجر ائه على حكم النحو" (؛) الاعز

(1):مصطفى عليان عبد الرحيم: تيارات النقد الأدبي في الأندلس في القرن الخامس الهجـري، ص . 17

(Y): لطفي عبد البليع: التركيب اللغوي للأدب، بحث في فلسفة اللغة والاسـتطيقا، مكتبـة

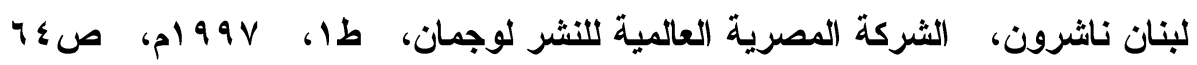

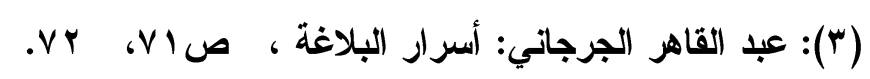

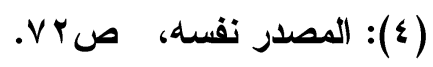




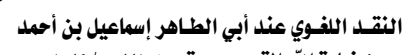

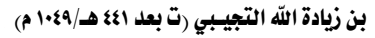
في كتابه (المختار من شعر بشار) اختيار الخاللديين

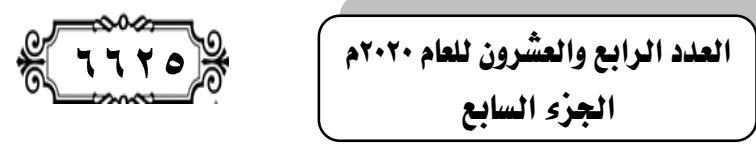

وعليه فإن فساد النظم عند التجيبي كما هو الحال عند سائر النقــاد

من اللغويين والنحاة- إنما يرجع إلى عدم مراعاة الثاعر للأصول والقواعد

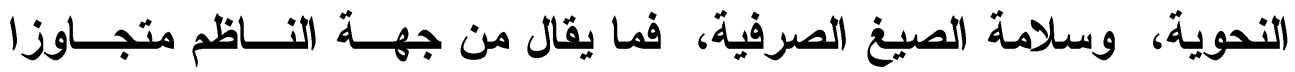

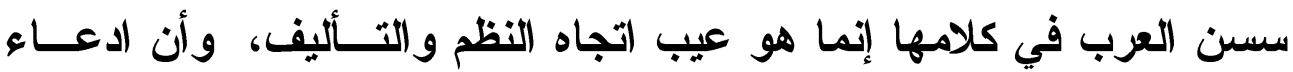
عكس ذلك معقود بناصية القواعد النحوية.

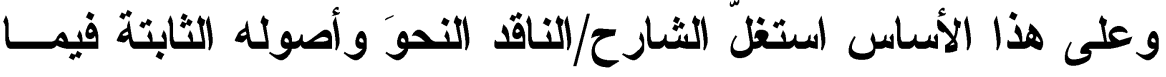

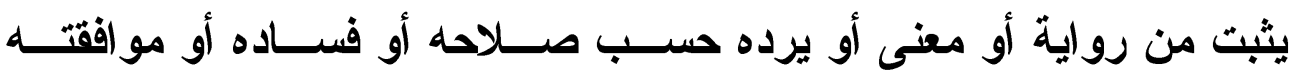
ومخالفته لتلك القو اعد والأصول.

فقد أورد بيتا من الثعر من قصيدة في سبعة أبيات وهو:

قالت تدعْنا بلا صُرم ولا صلة // / ولا صدود ولا في حال هجران (1)

ثم نقل رأي الزجّاجي في هذا البيت قائلا:" قال الزجــاجي: قولـــه ـ

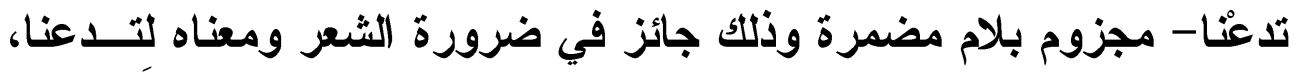

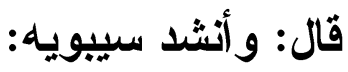

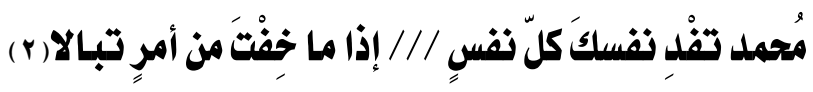

فقد أقر الثارح رأي غيره في هذه المسألة وحاول تصدير هذا الرأي والجمع بين القاعدة النحوية والضرورة الثعرية.

ولا يفوّت التجيبي فرصة الحديث عن الضبط النحسـوي وأثــره فــي

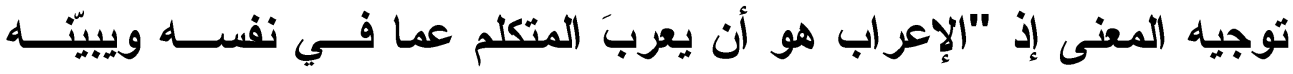

(1): المختار من شعر بشار، ص9 ؟ ـ.

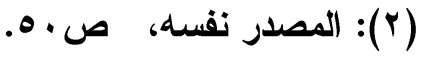

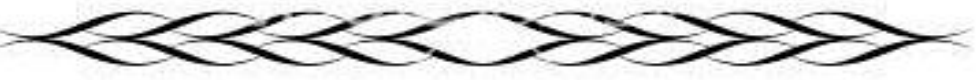


ويوضح الغرض ويكثف اللّبس."(1) ففي إيراده لبيت زينب بنت الطّترية في رثاء أخيها يزيد:

\section{مضَى وورثناه دريس مُفاضة // / وأبيض هندياّ طوالا حمائله}

يقول:" المفاضة الارع الواسعة التي أفيضت أي وستّت، والدريس

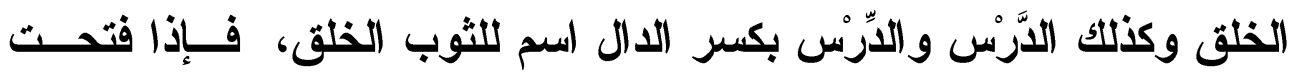

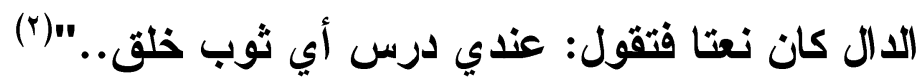

وهو في شروحاته وتفسير اته يتعرض لمسائل نحوية مهمة ويبـيّنُ

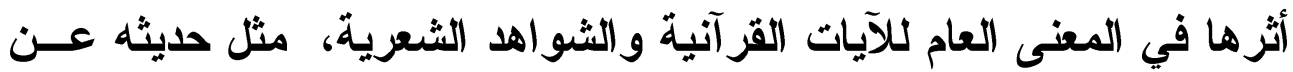

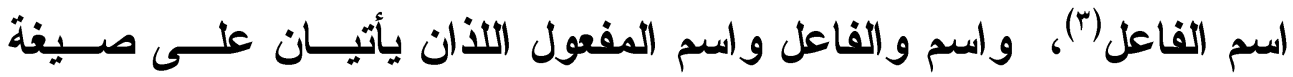

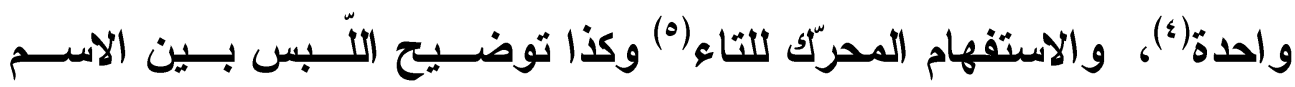

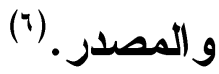

وهو في كل ذلك يدلي بدلوه في هذه القضايا التي يوردها ويفصل في

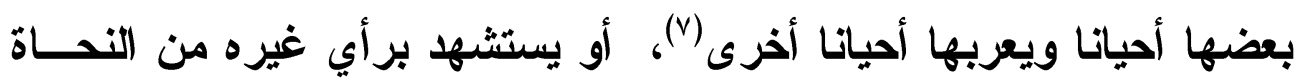

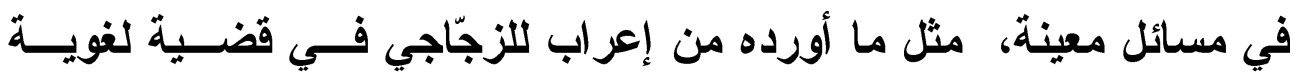

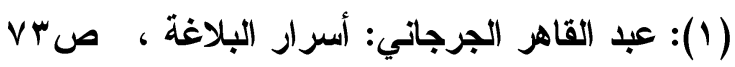

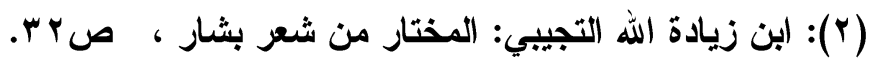

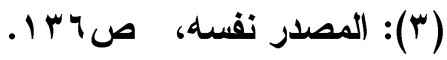

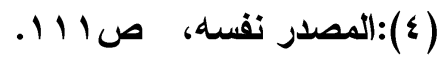

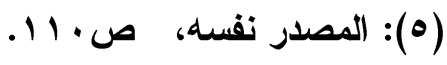

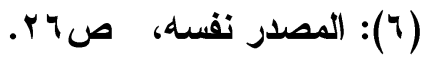

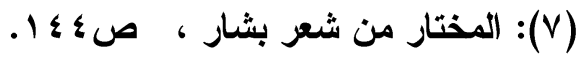




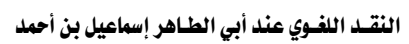

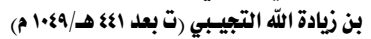
في كتابه (المختار من شعر بشار) اختيار الخالديين

معينة (1)، ويستمر على هذا النمط في إجراء أبيات أبي معاذ علــى أصــول

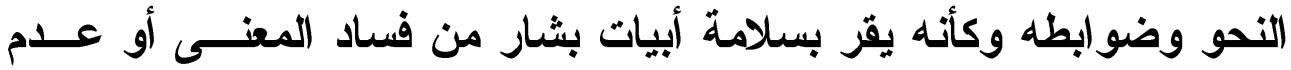
مجانبته للصو واب.

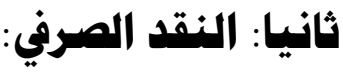

البحث في دلالة الألفاظ ومعانيها لا يتم إلا بمعرفة المواضيع الصرفية

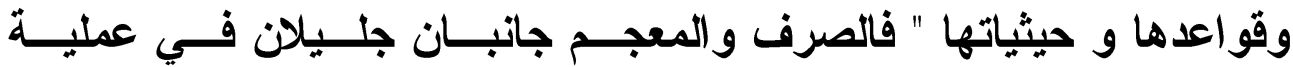

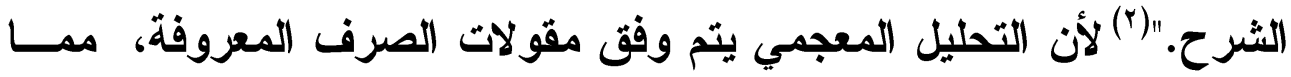

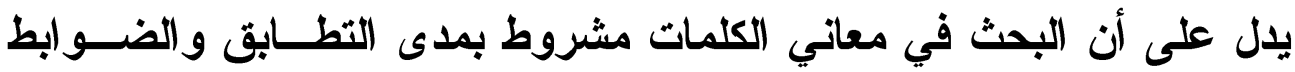
(الصرفية) (بان)

وقد سخّر المؤلف معارفه الصرفية حيث عني ببنية الكلمة اسما كاتت أو فعلا في شروحاته المختلفة، وذلك مــن عـدة زوايــا منــل: الحركــة

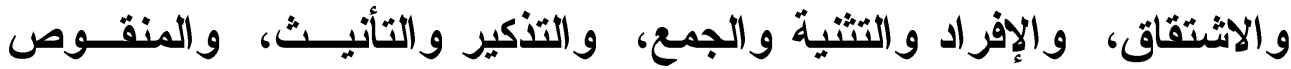

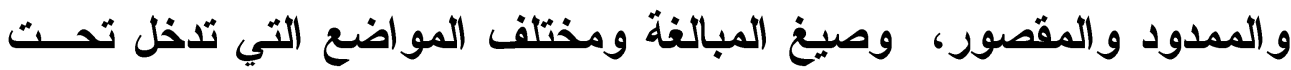
مسىى الصرف ، وكأن الناقد موقن بأن " رصد مميزات الكلمة في بنيتهـا

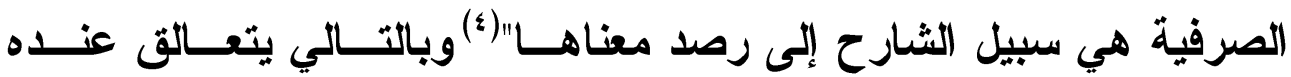
الصرف والالالة في سبيل خدمة الدرس اللغوي.

ها هو يقف مع مرثية أبي عبد الله بن مناذر الثهيرة في عبد المجيا

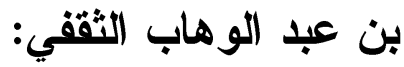

(1) :المصدر نفسه، صبץ 1)

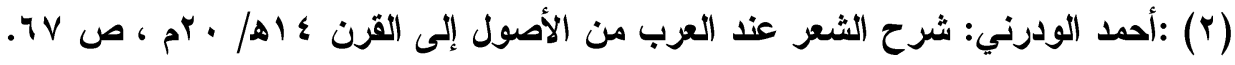

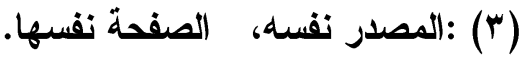

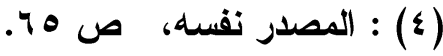




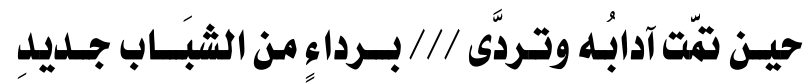

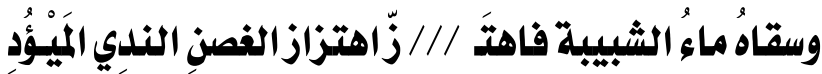

ثم يعلق على ذلك بقوله:" الميؤدُ المتثخىّ وهو فيعــول مــن المــأد،

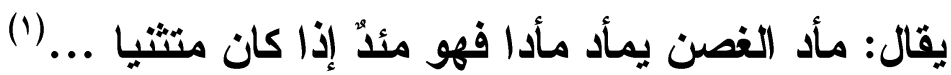

والظاهر أن الثارح خبيز باللقظ العربي في إفراده وجمعه وتثنيتــه،

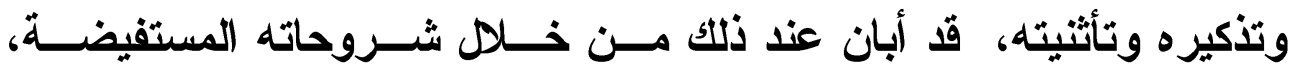
وتعليقاته المستوسعة، بعد عرضه لمختلف الأمثلة في مصــفه، شـــارحا إياها، مبينا وجه الصواب والاقة في استخدام هذه الصيغة أو تلك. (r) والأمر سيان في حديثه عن مواضــيع تخــص الجانـب الصــرفي كالمهموز والمقصور، والتعريف والتنكير، وأثز ذلك في المعنى العام للنص مع ذكر مختلف الآراء. (ّ) وفي شرحه لعينية بشار بن برد الشهيرة والتي مطلعها:

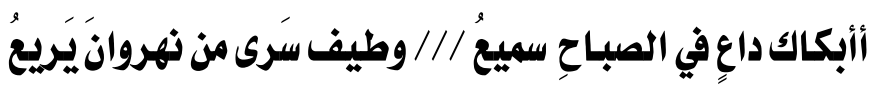

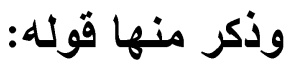

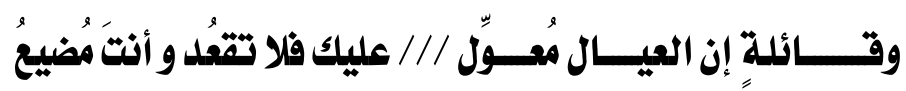

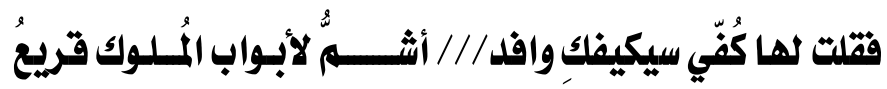

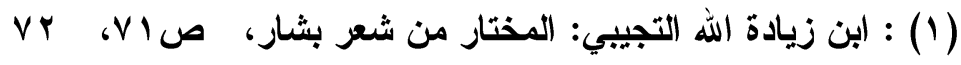

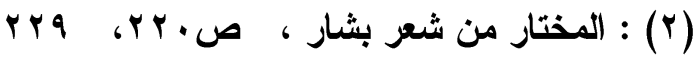

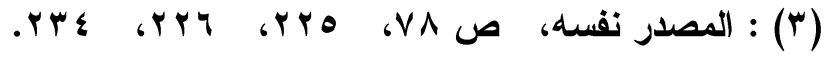


ثم أعقب ذللك قائلا: " المضيع اسم الفاعل من أضاع... وقروع اســـ

الفاعل من قرع الباب فهو قارع وقروع كضارب وضروب... ووسيع وواسع

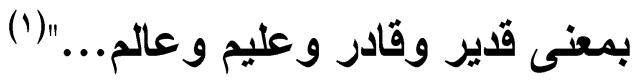

وفي موضع آخر من الكتاب يتحدث عن تصغير التعظيم الذي يـأتي

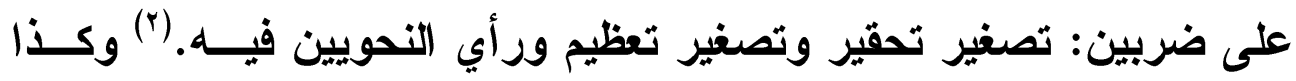

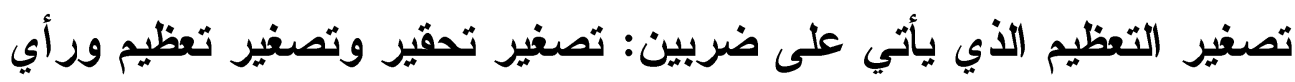
(النحويين فيه (كائميز

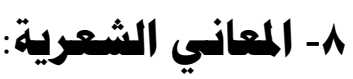

ليس بخاف على أهل النظر من النقاد وأصحاب الصناعة الثعرية أنّ أنّ

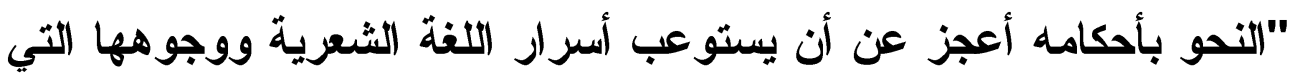

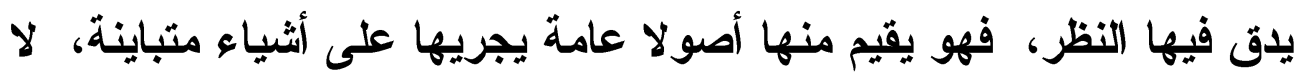

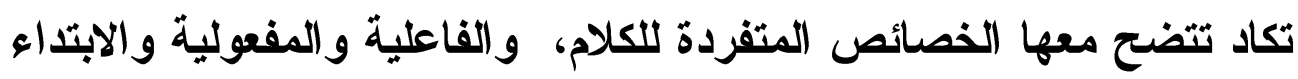

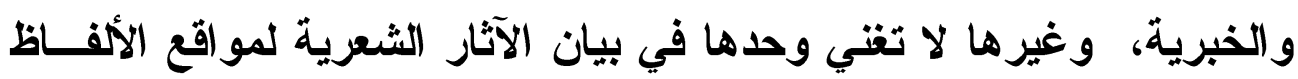

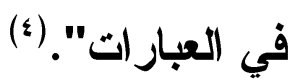

ولألك فالتثبت بأحكام النحو ومعانيه أفضى إلى غيــر قليـل إهـــال

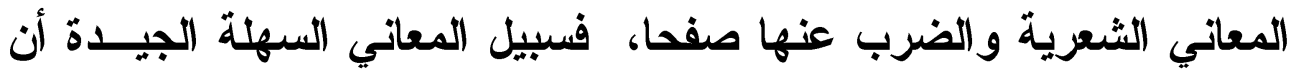

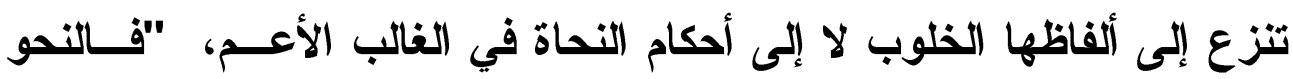

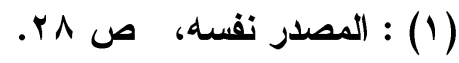

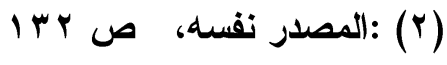

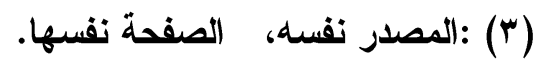

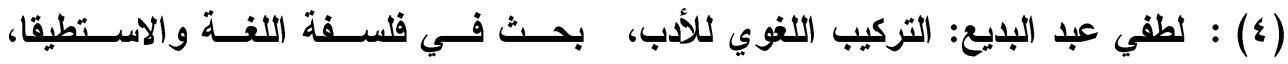

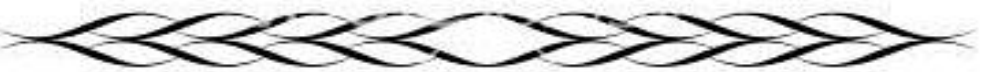


يستهل حياته بأن يعزز الاستعمال بالصــواب المنطقــي ويجــــي المعـــي

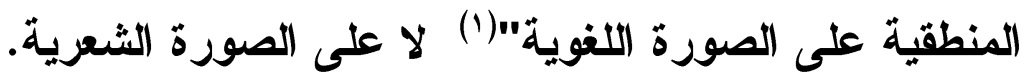

لذلك فليس من نافلة القول أن نذيل الحديث في ختام هذا المبحث عن

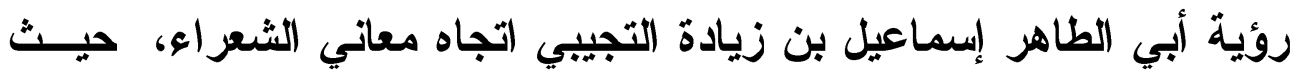

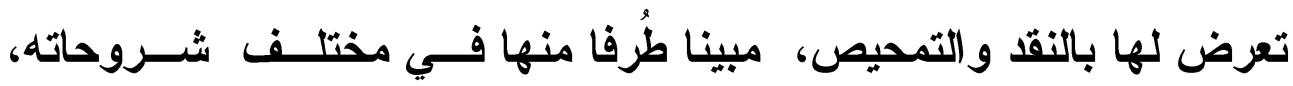
وهي روئة في غاية الأهمية في تقويم دلالة النصوص والمختارات الثعرية

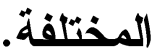

ويَستعمل في ذلك صيغا متعددة مثل: " أكمل معنى وأتمه"(") وقوله: "

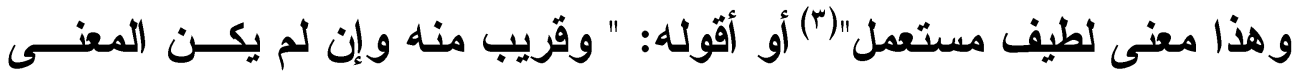

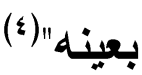

وكثير ا ما وقف عند بعض الأبيات الثعرية فعلق عليها قائلا: " وأما

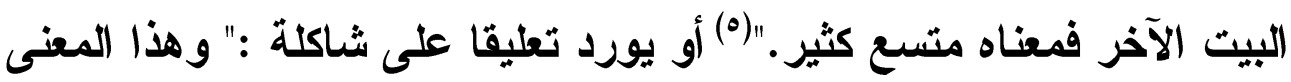

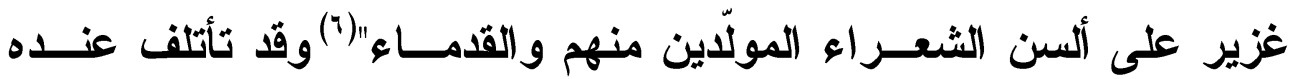

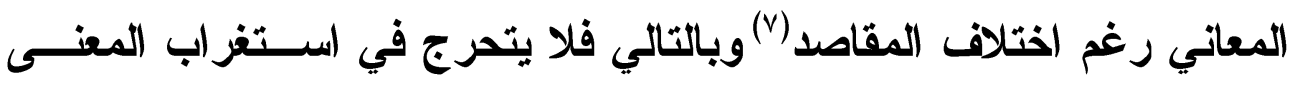
و استظر (فه في الوقت نفسه(^)وهو في كل هذا يجمع بين اللغوي الصارم في

(1) : : المصدر نفسه، الصفحة نفسها.

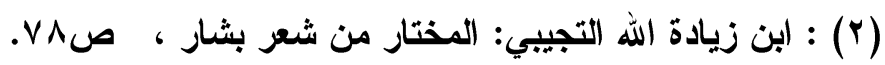

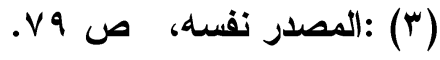

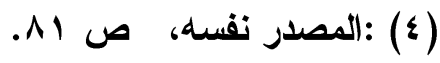

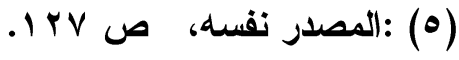

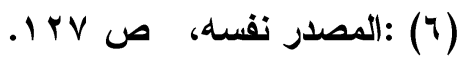

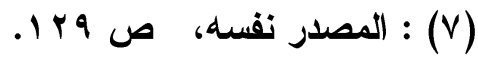

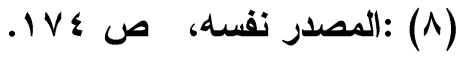




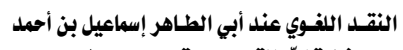

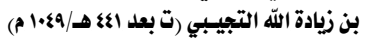
في كتابه (المختار مز شعر بشار) اختيار الخاللديين

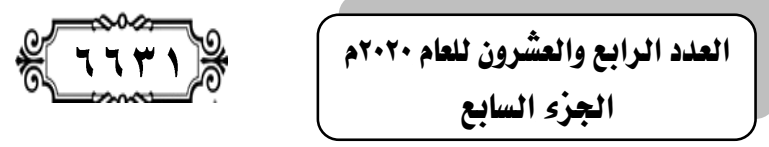

في قواعده، والأديب الماهر في صناعته، و والأي يحسن في شـــوذه عـن

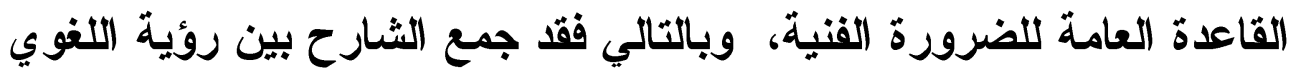
الناقد و الأديب الماهر .

ورغم ذللك فقد بقيت الصبغة اللغوية طاغية على كل أحكامه النقليــة

في هذا الشأن حيث لم يستطع منها فكاكا. 


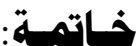

إذا كانت الاختيارات الثعرية تُعبرّ عن الحس النقدي الــــي يحُــوزه

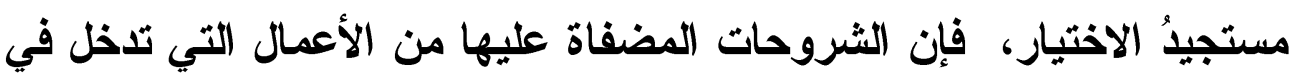

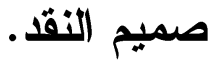

ويأتي شرح العلامة أبي الطاهر إسماعيل بن أحمد بــن زيــادة الله التجيبي البرقي في كتابه " المختار من شعر بشار، اختيار الخالدين" في هذا لفئر الثأن.

وبما أن الثارح لغوي" أساسا فإنّ شروحاته على اختيار الخالايين قـ

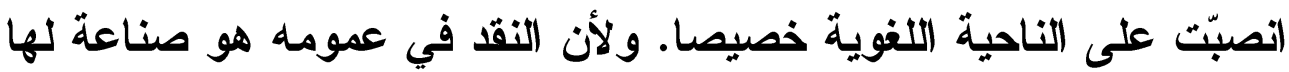

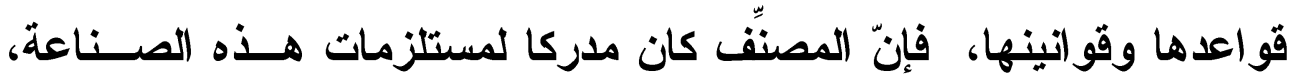
حيث احترف - عن وعي ويصيرة - كل ضرورات هذه الصناعة.

وعليه فقد كان مُوقنا بان النقد اللفوي هو القدرة على تفكيك مسادة

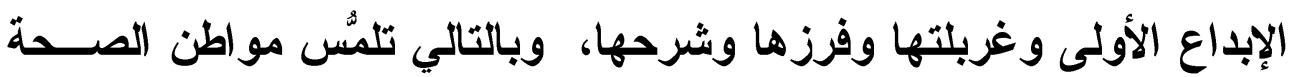
و الخطأ والجمال والقبح فيها واستيضاح كنهها وفظدّ منظلقاتها.

ومن خلال عرضنا للمادة يمكن أن نقول، إن النقا اللغوي الممارس

من طرف أبي الطاهر التجيبي من خلال مصنفه، إنما صدر عـن الثقافــة

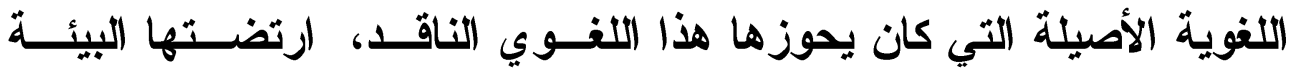
العلمية/اللغوية، والثقافية، و التي كان هو أحد محصلاتها. مع استناده في

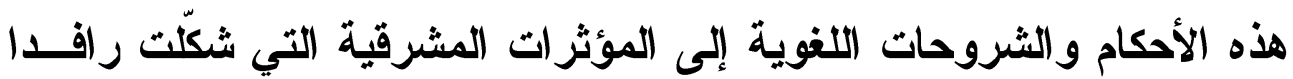

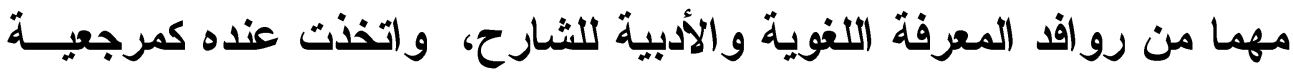
معرفية مهمة وأساسية في تلكك الشروحات والتعليقات.

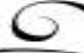




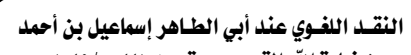

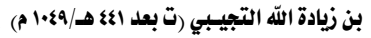
في كتابه (المختار مز شعر بشار) اختيار الخالديين

وهذه الروئة النقدية لأبي الطاهر في جانبها اللغوي، وإن أكدّت من

جهة سلامة هذا الذوق لشمولية ثقافته وسعة محفوظــه، وبالتــالي تميـز الروية النقدية للثارح وصو اب أحكامه وسلامة تفسير اته، ف فإنها أكدّت مسن جهة أخرى صحة الأحكام النقلية للتجيبي في الجاتب اللغوي، واستقامتها؛ لأنها نابعة من عمق الثقافة اللغوية الأصيلة التي تميز بها العلامة الجهابة المغاربي الكبير ، وهي أحكام صادرة عن وعي شخصية لها وزنها في هذا المجــال، وكل من ترجم له من القدماء من أصحاب التراجم والطبقات شهر له بذلك. و الملاحظ على المنهج المتّبع من طرف أبي الطاهر إبــماعيل فــي

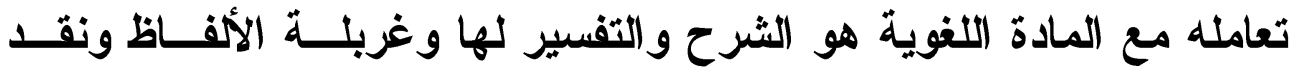

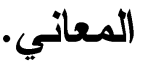

وتكتسي أحكامه النقدية في الجاتب اللغوي أبعادا جديدة مـن خــلد اعتماده على الموروث الثعبي والأسطوري بوصفه نقطة انطلاق مركزيــة نحو تفسير لغوي مقنع وحقيقي يستند إلى خلفيات معرفية أخرى وســياقية اقتضتها مناسبة النص.

ويمكن للمتمعّن في كتاب أبي الطاهر إسماعيل بن احمـــ التجيبـي

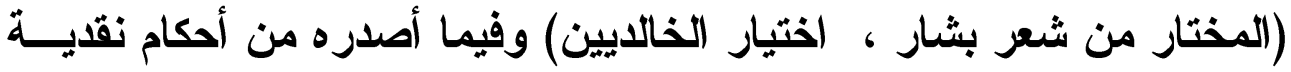

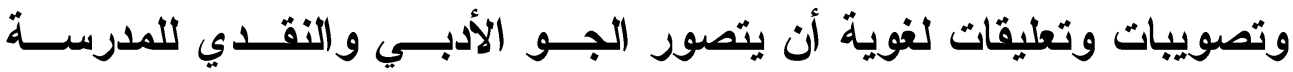
القيروانية في الغرب الإسلامي حيث كان أبو الطاهر أحد روّادهـا، و وهــي مناسبة مهمة نقف عندها بالكلام.

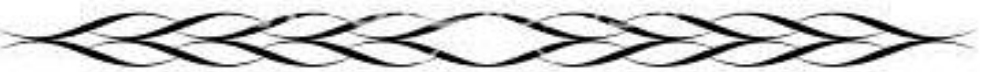




\section{ثبت المصادر والمراجع:}

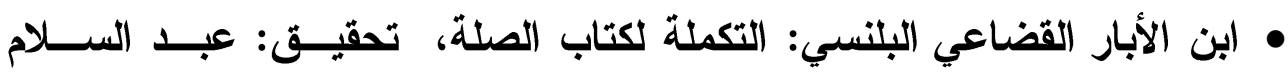

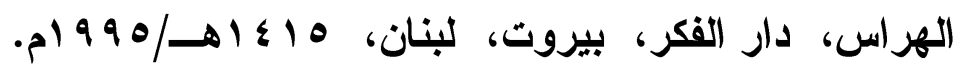

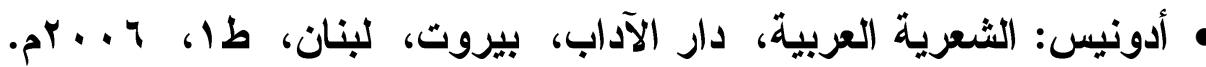

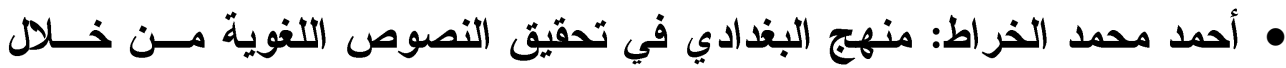

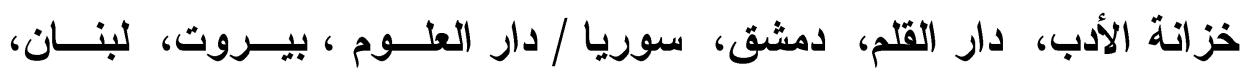

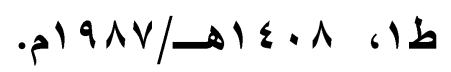

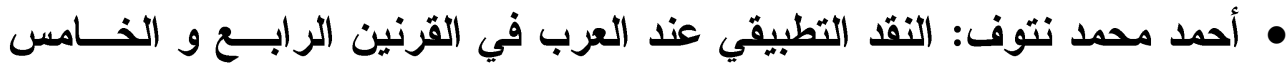

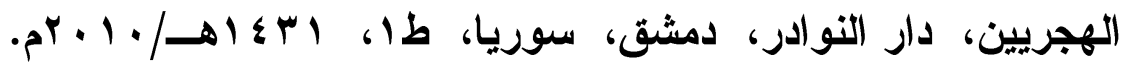
ه أحمد الودرني:

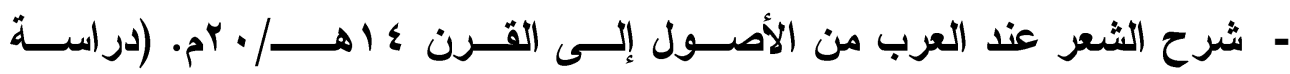

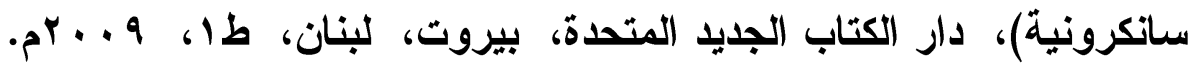

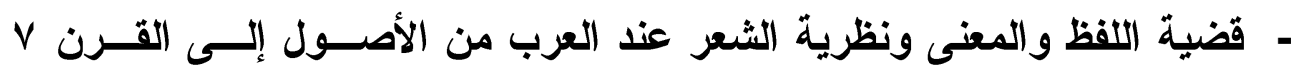

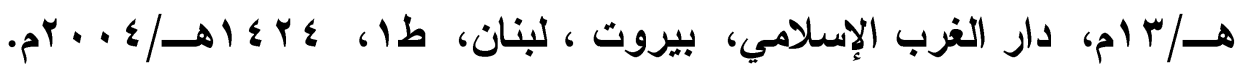

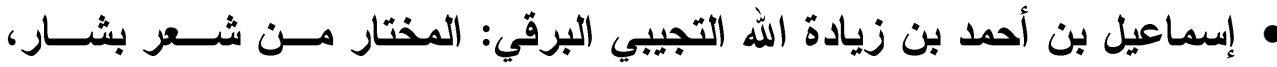

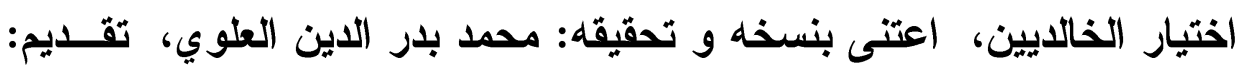

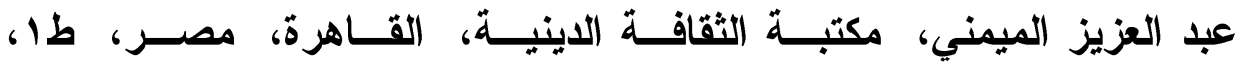

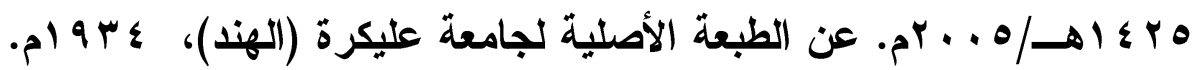

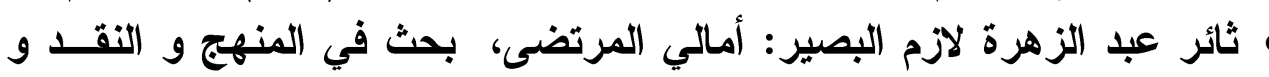

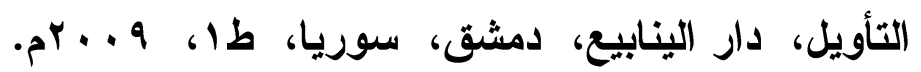

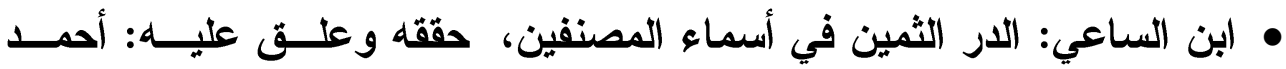

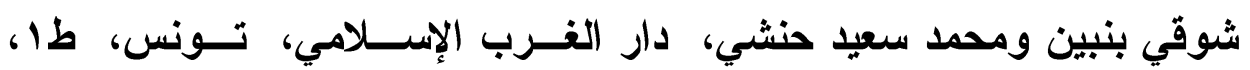
.

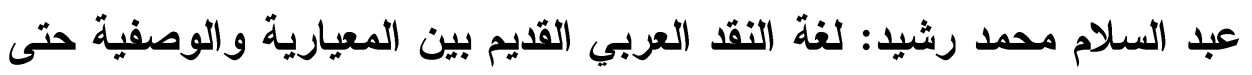

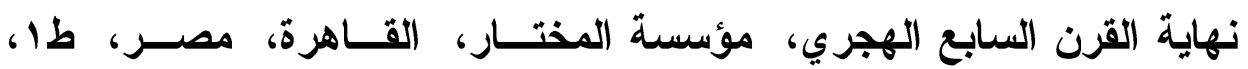
. $r$. $r / 1 \leqslant r q$ 
• السيوطي: بغية الوعاة في طبقات اللغويين و النحاة، تحقيـق: محمــد عبـــ

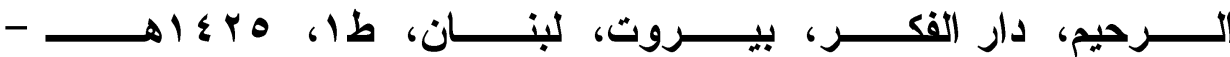

$$
\text { . . . . }
$$

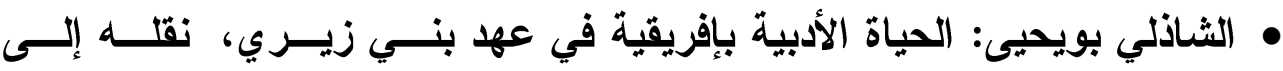

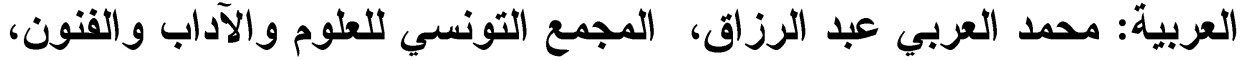

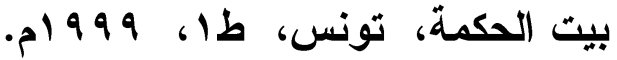
• طه مصطفى أبو كريشة: النقد العربي التطبيقي بين القديم والحديث، مكتبــة

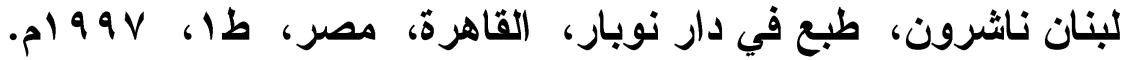

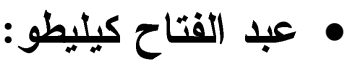

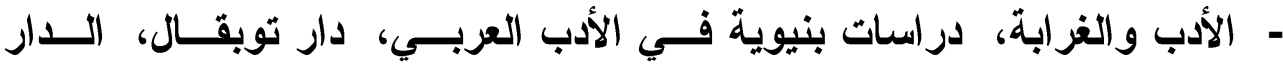

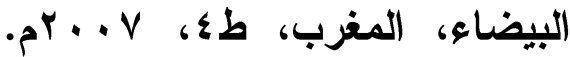

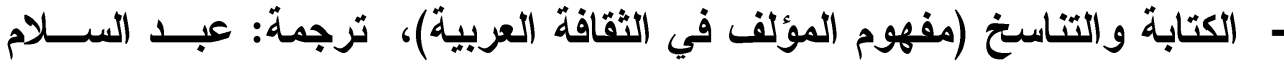

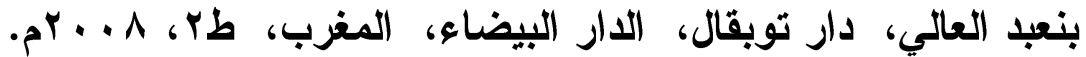

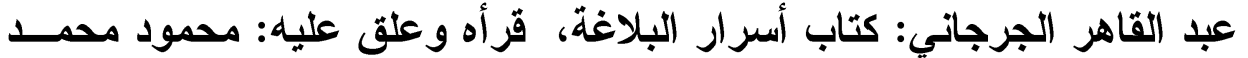

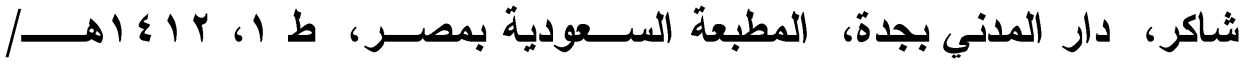
.91991 • ابن قتيبة: الثعر والثعراء، تحقيق وشرح: أحمد محمد شاكر، دار الحديث،

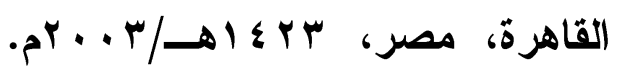
مصطفى عليان عبد الرحيم: تيارات النقد الأدبي في الأندلس في القرن الخامس

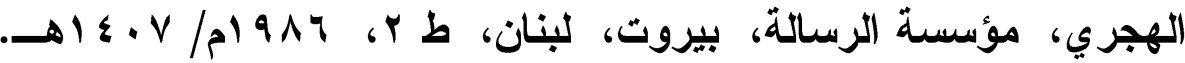

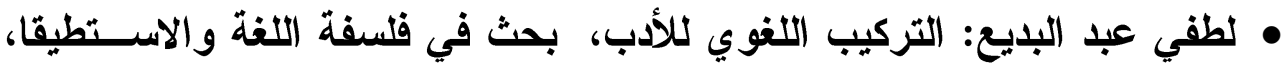

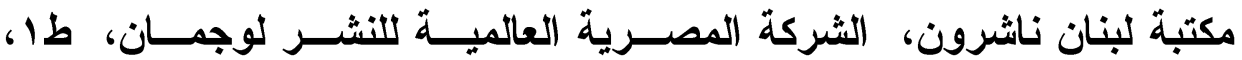
$.9199 \mathrm{~V}$ • ابن النديم: الفهرست، قابله على أصوله: أيمن فؤاد السيد، مؤسسة الفرقان

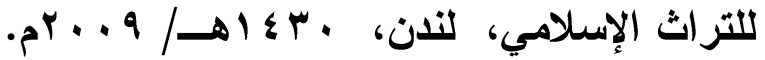

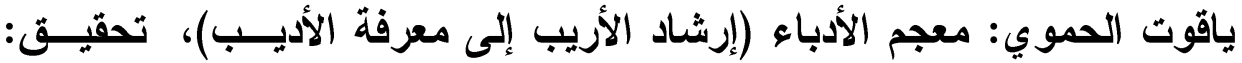

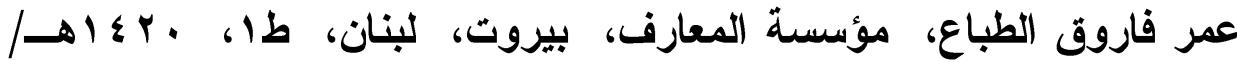

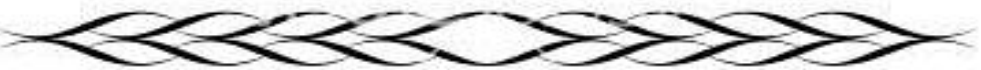


فهرس الإوضومات

\begin{tabular}{|c|c|c|}
\hline |لمفمة & الالوضـوع & $\hat{p}$ \\
\hline 7019 & هلفص & .1 \\
\hline 709. & Abstract & $r$ \\
\hline 7091 & التعريف بالإمألف: & r t r t \\
\hline 7o9r & آثـاره: & $\varepsilon$ \\
\hline 1098 & هنهج الهؤلف في الكتاب: & .0 \\
\hline $709 \mathrm{~V}$ & النقد اللغوي في كتاب أبي الطاهر إسماعيل التجيبي: & .7 \\
\hline 77.1 & أ-التفسير اللغوي (الشرح): & 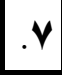 \\
\hline 7711 & ب- نقد الألفـاظ: &.$\Lambda$ \\
\hline Tyrr & ج- نقد المعاني: & .9 \\
\hline MTrr & خـاتمــة: & 1. \\
\hline 77rs & ثبت المسادر والمراجع: & 11 \\
\hline 77ry & فهرس الموضوعات & ir \\
\hline
\end{tabular}

